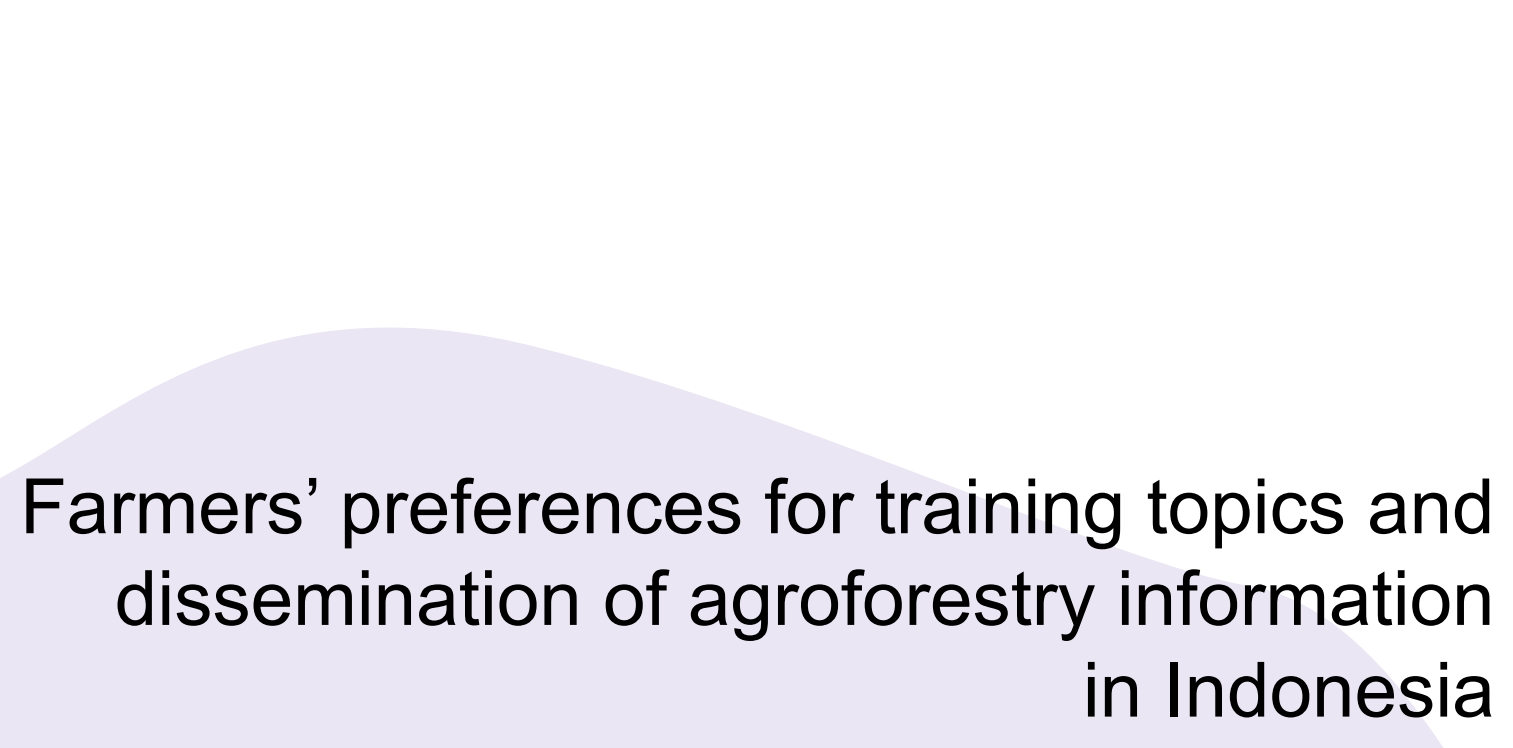





\section{Farmers' preferences for training topics and dissemination of agroforestry information in Indonesia}

Riyandoko and Endri Martini

Working Paper 284 


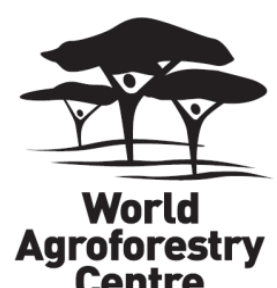

\section{Correct citation:}

Riyandoko and Martini E. 2018. Farmers' preferences for training topics and dissemination of agroforestry information in Indonesia. Working Paper 284. Bogor, Indonesia: World Agroforestry Centre (ICRAF) Southeast Asia Regional Program. DOI: http://dx.doi.org/10.5716/WP18015.PDF

Titles in the Working Paper Series aim to disseminate interim results on agroforestry research and practices and stimulate feedback from the scientific community. Other publication series from the World Agroforestry Centre include: Agroforestry Perspectives, Technical Manuals and Occasional Papers.

Published by the World Agroforestry Centre

Southeast Asia Regional Program

JL. CIFOR, Situ Gede, Sindang Barang, Bogor 16680

PO Box 161, Bogor 16001, Indonesia

Tel: +622518625415

Fax: +62 2518625416

Email: icraf-sea@cgiar.org; icraf-indonesia@cgiar.org

ICRAF Southeast Asia website: http://www.worldagroforestry.org/region/southeast-asia/

(C) World Agroforestry Centre 2018

Working paper no. 284

\section{Disclaimer and copyright}

The views expressed in this publication are those of the author(s) and not necessarily those of the World Agroforestry Centre. Articles appearing in this publication may be quoted or reproduced without charge, provided the source is acknowledged. All images remain the sole property of their source and may not be used for any purpose without written permission of the source. 


\section{About the authors}

Riyandoko is an agroforestry extension researcher with the World Agroforestry Centre (ICRAF) since 2015, working on issues related to the development of timber and non-timber production and market strategies for improving farmers' livelihoods in Indonesia. Previously, he was involved in the fields of education, extension and community development in various parts of Indonesia, including Sumatra, Java, Kalimantan, Sulawesi and Nusa Tenggara. Riyandoko holds a bachelor degree in animal husbandry from Universitas Wangsa Manggala Yogyakarta.

Endri Martini is an agroforestry extension researcher with the World Agroforestry Centre (ICRAF) since 2011. She has been part of ICRAF since 2001, working on various agroforestry topics, such as biodiversity conservation and community-based natural resources management. She obtained her bachelor degree from the Silviculture Department of the Faculty of Forestry, Institut Pertanian Bogor, and her master degree in Natural Resource and Environmental Management from the University of Hawaii at Manoa, Hawaii, USA. 


\section{Abstract}

Agroforestry has been implemented by farmers in Indonesia for a very long time. Various studies of agroforestry have been conducted either by local or foreign research institutions. One of these research projects, Development of Timber and Non-timber Forest Products' Production and Market Strategies for Improvement of Smallholders' Livelihoods in Indonesia, which was implemented by the World Agroforestry Centre (ICRAF) with funding from the Australian Centre for International Agricultural Research (ACIAR) (FST 2012-039), examined production and market strategies for timber and non-timber forest products, 2012 to 2017. The project produced research results that were then disseminated to farmers through training sessions, with the expectation that this would help improve the livelihoods of agroforestry farmers in various parts of Indonesia. Farmers will adopt the information or knowledge provided through training if they are interested in the topic. They tend to circulate such information to other farmers. This study was conducted to explore farmers' preferences for training or extension topics and information dissemination in Sumbawa District, West Nusa Tenggara Province; Gunung Kidul District, Special Region of Yogyakarta Province; and South Timor Tengah District, East Nusa Tenggara Province. Semi-structured interviews were carried out from March to June 2016 to collect information on farmers' preferences for training topics, acceptance of new agroforestry technologies, and expected training or extension services on agroforestry subjects. Evaluation of training and extension activities by participants was also conducted to acquire feedback for improvement of future agroforestry training or extension. Interviews were conducted with 110 respondents (farmers), 56 of whom were participants of training and extension activities carried out by the project team and the remaining 54 were non-participants of such training and extension activities; $29 \%$ of total respondents were female. Respondents were randomly chosen from among participants of agroforestry and forestry training or extension activities conducted in the previous year in each district and farmers who were not participants. Qualitative and quantitative data analyses were conducted. The results showed that farmers from the three districts preferred agroforestry extension focusing on silviculture, agroforestry farm management, and agroforestry product marketing. Farmers' preferences for extension topics varied depending on location and gender. In terms of information dissemination, extensionists played an important role as sources of information for farmers. Female farmers with less access to extensionists depended on family, farmers' associations and 'champion' or leading farmers as their sources of agroforestry information. In areas with limited road access and other infrastructure, such as Nusa Tenggara, sources of agroforestry information were limited compared to more developed areas, such as Gunung Kidul in the Special Region of Yogyakarta. Reliable sources of information, and technology with simple characteristics and appropriateness for specific areas, affected farmers' adoption of technology. For improvement purposes, delivery of agroforestry training or extension in the three districts should focus more on production and marketing of timber and non-timber forest products, taking into consideration participants' backgrounds, methods, materials, time and duration of the training or extension activity. 
Keywords: Gunung Kidul, Sumbawa, South Timor Tengah, extension topics, information, farmer, agroforestry 


\section{Acknowledgements}

This study was carried out with funding from the Australian Centre for International Agricultural Research to the Development of Timber and Non-timber Forest Products' Production and Market Strategies for Improvement of Smallholders' Livelihoods in Indonesia (FST/2012/039 [KANOPPI]). The authors would like to express their gratitude to respondents from Sumbawa, Gunung Kidul and South Timor Tengah for their time and welcome to researchers for providing the necessary information for this study. The authors would also like to express their gratitude to KANOPPI partners at the study sites: Mr Junaidin of Batudulang Village, Sumbawa; Mr Suwardi of Pelat Village, Batudulang, Sumbawa; Extension Implementation Agency of Unter Iwes District, Sumbawa; Mr Sumardamto Purnomo; Gunung Kidul District Forestry and Plantation Department; Kelompok Kerja Hutan Rakyat Lestari of Gunung Kidul District; Extension and Food Security Agency of Gunung Kidul; and the Forestry Department and Extension and Food Security Agency of South Timor Tengah for their support in gathering data at each location. Our gratitude also goes to Mrs Subekti Rahayu and Mr Robert Finlayson for their assistance in editing this paper. We would also like to thank Pémad International Translations who provided service to translate this paper from Indonesian to English. Finally, we wish to express our gratitude to Mr Aulia Perdana, KANOPPI project leader, for his support and input at each stage of this study. 


\section{Contents}

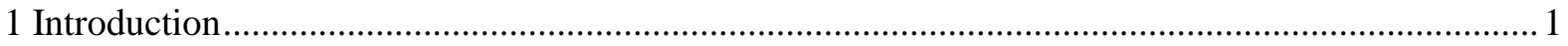

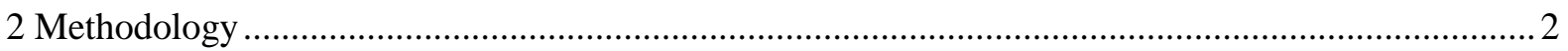

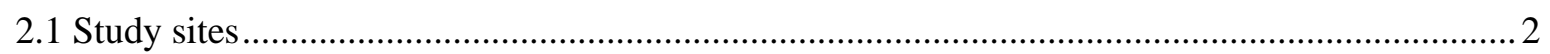

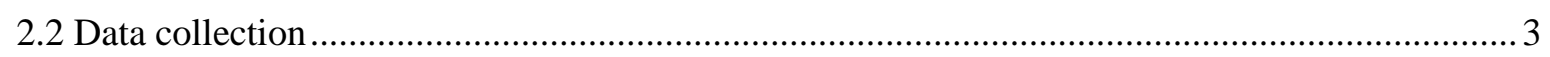

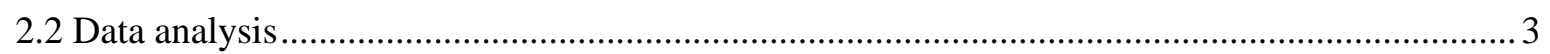

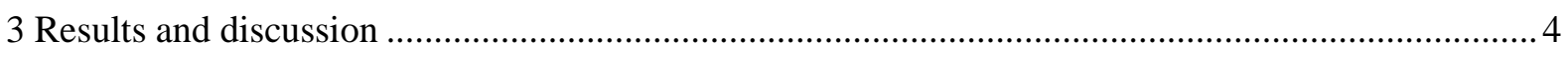

3.1 Training for voluntary extensionists and champion farmers ................................................ 4

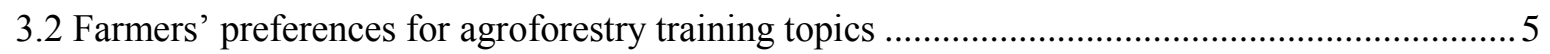

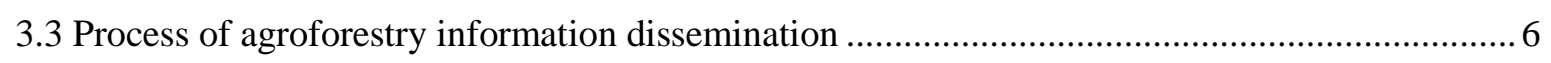

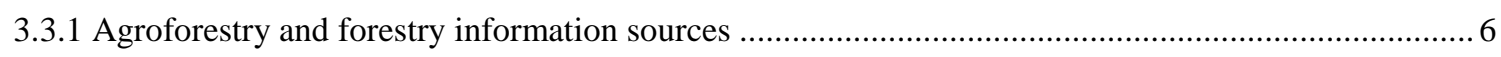

3.3.2 Agroforestry and forestry information dissemination as a result of training held by KANOPPI....... 11

3.4 Relation between sources of information, information topic and adoption process ................... 14

3.5 Developing agroforestry training or extension services based on farmers' needs..................... 15

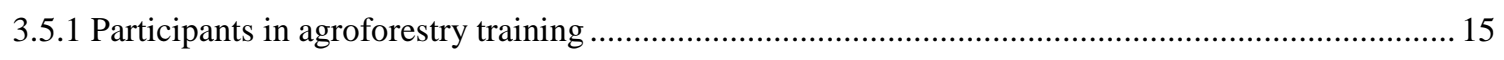

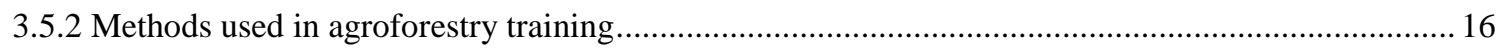

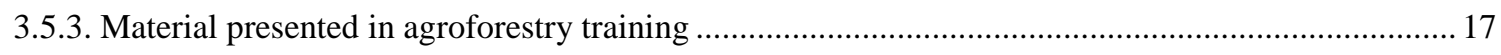

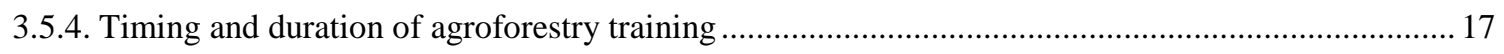

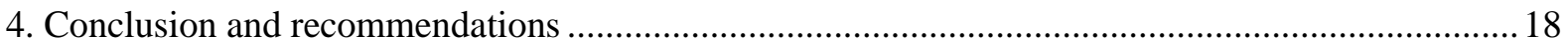

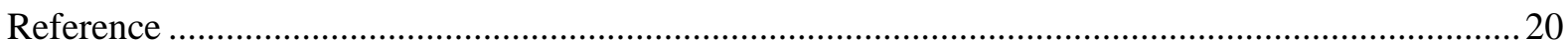




\section{List of Tables}

Table 1. Characteristics of study sites in Gunung Kidul, Sumbawa and South Timor Tengah districts 2

Table 2. Numbers of respondents in each district, disaggregated by gender 3

Table 3. Number of training participants on timber and non-timber forest products in Gunung Kidul,

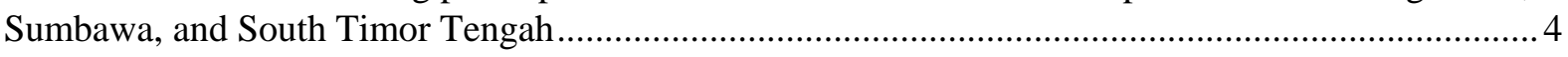

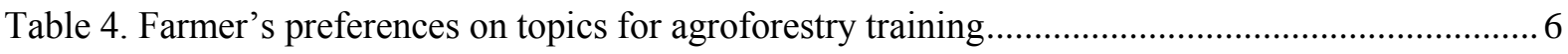

\section{List of Figure}

Figure 1. Map of KANOPPI project sites where training for voluntary extensionists and champion

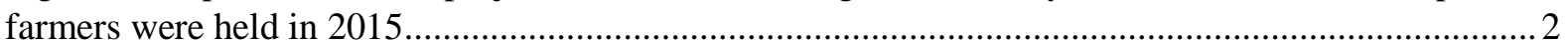

Figure 2. Networks of information sources in all studied districts, by gender ................................... 7

Figure 3. Variations in priorities of sources of information on agroforestry and forestry in Gunung

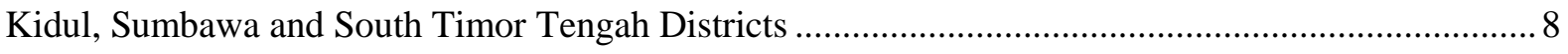

Figure 4. Networks of information sources for male and female farmers and voluntary extension

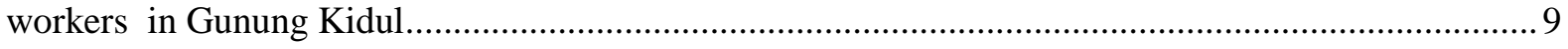

Figure 5. Networks of information sources for male and female farmers and voluntary extension

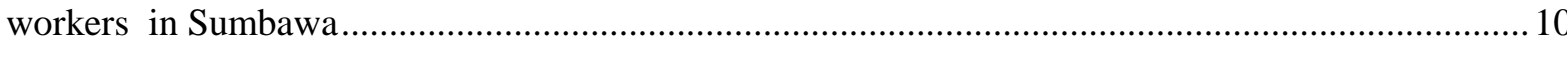

Figure 6. Networks of information sources on agroforestry and forestry for male and female farmers

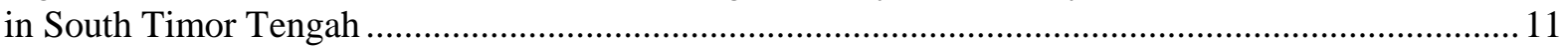

Figure 7. Network of farmers' information sources on timber and non-timber forest products ........... 12

Figure 8. Network of farmers' information sources on marketing of timber and non-timber forest

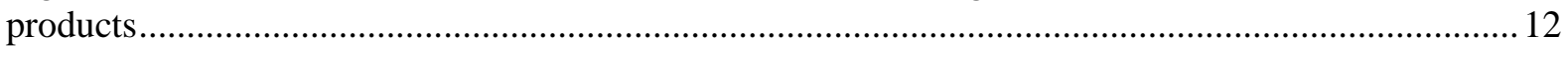

Figure 9. Farmers' information sources network on policy on the administration of forest products on

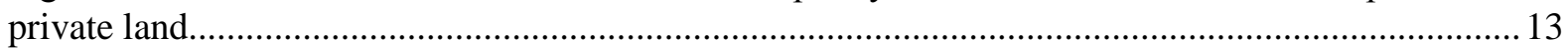

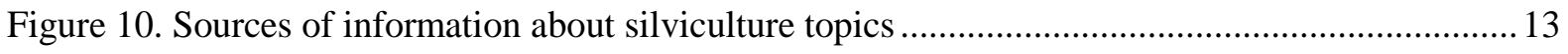

Figure 11. Network of sources of information about agroforestry farm management......................... 14

Figure 12. Farmers' perceptions of factors affecting the adoption of agroforestry technology ............ 15

Figure 13. Criteria for selecting training and extension participants based on respondents' inputs ..... 16

Figure 14. Respondents' preferred methods for agroforestry training or extension ............................ 16

Figure 15. Recommended duration of training or extension for both male and female participants.... 18 


\section{Introduction}

Agroforestry as a form of land management has been practised for many hundreds of years in Indonesia (Hairiah et al 2003). Modern agroforestry is a combination of forestry and agricultural techniques and systems developed to align agricultural intensification with forest conservation (de Foresta et al 2000). Put simply, agroforestry involves integration of trees, annual crops, and/or livestock on farms and in landscapes. In practice, agroforestry is classified into two: 1) simple agroforestry; and 2) complex agroforestry (Nair 1993). Simple agroforestry is a system involving intercropping one or more annual crop species between one species of tree. Complex agroforestry involves more than one tree species with annual crops and/or livestock on the same piece of land. The type of trees that can be integrated in agroforestry systems include both timber and non-timber species, such as fruit and exudates (for example, rubber latex).

Even though farmers have long been integrating various types of trees, optimum yields are often not achieved. This is often due to farmers' limited knowledge of tree cultivation (silviculture), measurement of timber volume, best practices in agroforestry management, marketing of timber and non-timber products, and policies on management of privately-owned tree products (Putro et al 2015). Weak extension services, owing to a limited number of government agricultural and forestry extensionists with a corresponding limited knowledge of agroforestry, has restricted farmers' ability to gain knowledge of agroforestry. Based on a baseline study conducted by KANOPPI, the percentages of farmers who were able to access agroforestry, or forestry, extension services were $41 \%$ in Gunung Kidul District, 30\% in Sumbawa District, and 14\% in South Timor Tengah District (Riyandoko et al 2016a).

To support the improvement of extension workers' capacity in Gunung Kidul, Sumbawa and South Timor Tengah Districts, the World Agroforestry Centre (ICRAF) and its partner provided training for voluntary extensionists and 'champion' or leading farmers in 2015. The topics presented during the four-day training were 1) introduction to timber and non-timber forest products; 2) policies regarding management of privately-owned tree products; 3 ) marketing of timber and non-timber forest products; 4) timber trees' cultivation; 5) timber and non-timber forest products' integrated into farm management (agroforestry); and 6) extension communication (Riyandoko et al 2016b). Training participants were expected to disseminate the information acquired to other farmers and voluntary extensionists. The participants' willingness to disseminate information was affected by their preferences for the training topics. If participants were interested in the topics, they were more likely to disseminate the information to others. This study aimed to 1) explore farmers' preferences for training topics; and 2) understand the process of agroforestry information dissemination acquired from training. 


\section{Methodology}

\subsection{Study sites}

The study took place at research sites that had conducted training in the production and marketing of timber and non-timber forest products from agroforesty systems (Figure 1). Each site had different types of tree species and products as well as other distinctive characteristics, such as dominant ethnicity and daily language used by farmers (Table 1).

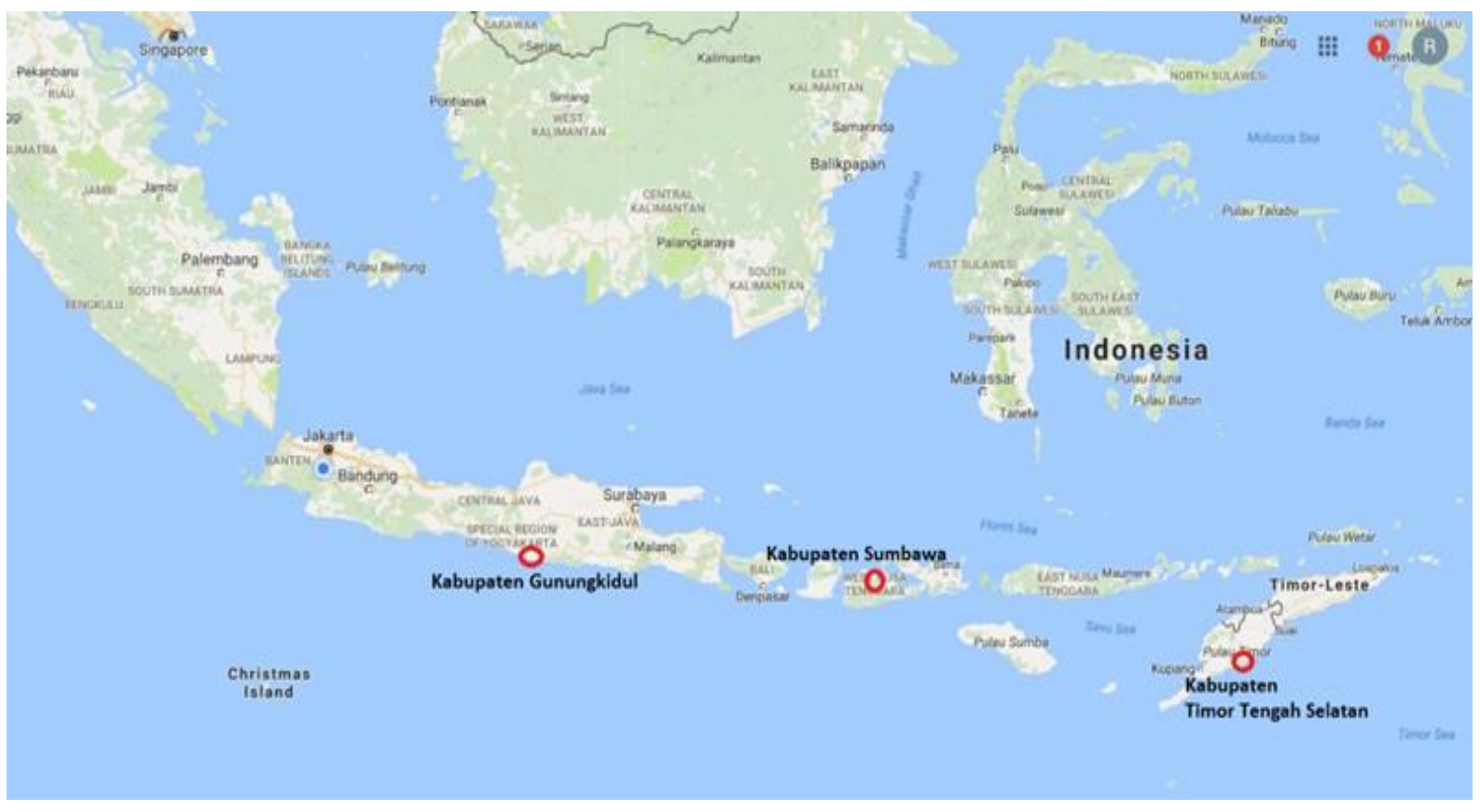

Figure 1. Map of KANOPPI project sites where training for voluntary extensionists and champion farmers were held in 2015

Source: Google maps 2016

Table 1. Characteristics of study sites in Gunung Kidul, Sumbawa and South Timor Tengah districts

\begin{tabular}{lllll}
\hline District, province & \multicolumn{2}{l}{ Type of crop in agroforestry farm } & $\begin{array}{l}\text { Main } \\
\text { ethnicity }\end{array}$ & $\begin{array}{l}\text { Daily language of } \\
\text { farmers }\end{array}$ \\
\cline { 2 - 3 } & Timber & Non-timber product & Javanese & Javanese, Indonesian \\
$\begin{array}{l}\text { Gunung Kidul, } \\
\begin{array}{l}\text { Special Region of } \\
\text { Yogyakarta }\end{array}\end{array}$ & $\begin{array}{l}\text { Teak, mahogany, } \\
\text { albizia, white } \\
\text { albizia }\end{array}$ & $\begin{array}{l}\text { White ginger, ginger, } \\
\text { cassumunar ginger, } \\
\text { turmeric }\end{array}$ & Javan & \\
\hline $\begin{array}{l}\text { Sumbawa, West } \\
\text { Nusa Tenggara }\end{array}$ & Teak & $\begin{array}{l}\text { Candlenut, ginger, } \\
\text { honey }\end{array}$ & Sumbawan & Indonesian, \\
\hline South Timor Tengah & $\begin{array}{l}\text { Gmelina, } \\
\text { mahogany }\end{array}$ & $\begin{array}{l}\text { Candlenut, ginger, } \\
\text { bamboo }\end{array}$ & $\begin{array}{l}\text { Molloan, } \\
\text { Aloran }\end{array}$ & Molloan \\
\hline
\end{tabular}




\subsection{Data collection}

The study of farmers' preferences for training topics and information dissemination was conducted between March and June 2016, 6-12 months after the voluntary extensionists and champion farmers had completed their training. Data were collected in the three districts through semi-structured interviews with 110 respondents consisting of farmers and voluntary extensionists, $29 \%$ of whom were female. Respondents were classified into two groups: 1) training participant; and 2) nonparticipant. Respondents in Sumbawa and South Timor Tengah were farmers and champion farmers while respondents in Gunung Kidul were voluntary extensionists appointed by the local government through a decree of the Extension and Food Security Agency of Gunung Kidul District. The total number of respondents in Sumbawa District was 39, from Pelat and Batudulang villages; in South Timor Tengah District it was 41, from Netpala, Bosen and Ajobaki villages; in Gunung Kidul District it was 30, from Tepus, Girisubo, Semanu, Patuk, Nglipar, Ngawen, Paliyan, Semin, Panggang, Saptosari and Karangmojo sub-districts (Table 2). The total number of respondents who were training participants differed from the total number of training participants owing to some participants being no longer domiciled in at the sites or were unavailable for interview.

Table 2. Numbers of respondents in each district, disaggregated by gender

\begin{tabular}{llllll}
\hline \multirow{2}{*}{ District } & \multicolumn{2}{l}{ Participants } & \multicolumn{2}{l}{ Non-participants } & Total \\
\cline { 2 - 6 } & Male & Female & Male & Female & \\
\hline Gunung Kidul & 19 & - & 6 & 5 & 30 \\
\hline Sumbawa & 11 & 8 & 15 & 5 & 39 \\
\hline $\begin{array}{l}\text { South Timor } \\
\text { Tengah }\end{array}$ & 13 & 5 & 14 & 9 & 41 \\
\hline
\end{tabular}

Information collected in this study were 1) sources of information for farmers on forestry and agroforestry; 2) farmers' acceptance of newly acquired knowledge or technology; 3) ranking of the most interesting training topics according to training participants; and 4) respondents' feedback for future training or extension to provide more benefit and impact. Some of the questions asked of participants were different than those asked of non-participants. For example, non-participants were not asked any questions regarding post-training follow up.

\subsection{Data analysis}

Collected data were then analyzed in both quantitative and qualitative manners. The Kruskal-Wallis Rank Sum statistical analysis was used to analyze farmers' preferences for training topics. Subsequently, a qualitative analysis of supporting factors affecting farmers' preferences was conducted. Social Network Analysis was used to analyse dissemination of information about agroforestry and forestry. The data analyses in this study used SYSTAT 11 software for KruskalWallis and Node XL for social networks. 


\section{Results and discussion}

\subsection{Training for voluntary extensionists and champion farmers}

Training for voluntary extensionists and champion farmers was conducted in 2015 in Sumbawa, South Timor Tengah and Gunung Kidul. The training was attended by 73 participants, $26 \%$ of whom were female farmers (Table 3). Participants attending the training in Sumbawa and South Timor Tengah were farmers and champion farmers recommended by farmers' groups, village administrators, and sub-district extension agencies. A champion farmer is one possessing more experience and knowledge than that of other farmers and who is prepared to be a voluntary extensionist under the local extension agency. In total, 49 farmers participated in the training, 32.7\% of whom were female. Training participants in Gunung Kidul were 19 voluntary extensionists appointed under a decree of the head of the sub-district extension agency. Fifteen (15) government extensionists participated in the training, from forestry and agriculture agencies and forest management units at each site.

Table 3. Number of training participants on timber and non-timber forest products in Gunung Kidul, Sumbawa, and South Timor Tengah

\begin{tabular}{|c|c|c|c|c|c|c|c|}
\hline \multirow{3}{*}{ District } & \multirow{3}{*}{ Time (Duration) } & \multicolumn{6}{|c|}{ Number of participants } \\
\hline & & \multicolumn{2}{|c|}{$\begin{array}{l}\text { Champion } \\
\text { farmer }\end{array}$} & \multicolumn{2}{|c|}{$\begin{array}{l}\text { Voluntary } \\
\text { extensionist }\end{array}$} & \multicolumn{2}{|c|}{$\begin{array}{l}\text { Government } \\
\text { extensionist }\end{array}$} \\
\hline & & M & $\mathrm{F}$ & M & $\mathrm{F}$ & M & $\mathrm{F}$ \\
\hline Sumbawa & $\begin{array}{l}\text { 11-14 May } 2015 \\
\text { (four days) }\end{array}$ & 11 & 10 & 0 & 0 & 3 & 1 \\
\hline $\begin{array}{l}\text { South Timor } \\
\text { Tengah }\end{array}$ & $\begin{array}{l}\text { 20-22 October } 2015 \\
\text { (three days) }\end{array}$ & 12 & 6 & 0 & 0 & 4 & 2 \\
\hline Gunung Kidul & $\begin{array}{l}\text { 14-17 Dec } 2015 \\
\text { (four days) }\end{array}$ & 0 & 0 & 19 & 0 & 5 & 0 \\
\hline
\end{tabular}

Note: $\mathrm{M}=$ male; $\mathrm{F}$ = female. Source: Training report data, 2015.

Topics studied in the training were 1) introduction to timber and non-timber forest products; 2) policies regarding private forest products' management; 3) timber and non-timber products' marketing; 4) timber trees' maintenance (silviculture); 5) timber and non-timber products' integrated into farm management (agroforestry); and 6) extension communication and information dissemination (the syllabus is provided in Appendix 1). According to the syllabus, all training topics were delivered in four days but the execution was based on initial agreements and learning contracts between participants and facilitators. In Sumbawa and Gunung Kidul, training was conducted in four days; in South Timor Tengah it took three days. The decision to hold three-day training, instead of four, in South Timor Tengah was based on mutual agreement between participants and the facilitator because one of the planned four days coincided with market day, which is when farmers usually engage in trading. 
Training implementation at each site was successful, with strong support from governmental agencies as well as local non-governmental organization.

1) Training in Sumbawa was held in cooperation between KANOPPI and WWF Indonesia's Nusa Tenggara program, Institute of Non-Timber Forest Products' Research and Technology (Balai Penelitian dan Teknologi Hasil Hutan Bukan Kayu/BPTHHBK) Mataram, Universitas Mataram, and the Agriculture, Fishery, and Forestry Extension Implementation Agency (Badan Pelaksana Penyuluhan Pertanian, Perikanan dan Kehutanan/ BP4K) of Sumbawa District.

2) Training in South Timor Tengah was held in cooperation between KANOPPI and the Extension and Forestry agencies (Badan Penyuluhan and Dinas Kehutanan);

3) Training in Gunung Kidul was held in cooperation between KANOPPI, the Forestry and Plantation Agency of Gunung Kidul and the Extension Agency of Gunung Kidul District.

\subsection{Farmers' preferences for agroforestry training topics}

In this study, farmers' preferences for, or interest in, extension topics was observed by ranking the most interesting training material according to training participant. The Kruskal-Wallis analysis showed respondents' preference ranking of training material in all districts, in sequential order: 1) timber trees' maintenance (silviculture); 2) timber and non-timber forest products' integrated farm management; 3) timber and non-timber forest products' marketing; 4) management policies regarding private forest products; 5) extension communication; and 6) introduction to timber and non-timber forest products.

Respondents' preferences for training material were affected by their need for training and extension in basic farming practices. From those six topics, timber trees' maintenance (silviculture) and timber and non-timber forest products' integrated farm management (agroforestry) were practical topics on farming, meeting their basic need to cultivate their farms.

In addition to their need for practical and basic knowledge, advanced analysis showed farmers' preferences for training topics were also affected by regional factors and gender roles. Male farmers in the three districts tended to prefer similar training topics, that is, timber trees' maintenance (silviculture) followed by non-timber forest products' integrated farm management (agroforestry), and timber and non-timber forest products' marketing. Female farmers' preferences varied between locations. 
Table 4. Farmer's preferences on topics for agroforestry training

\begin{tabular}{|c|c|c|c|c|c|c|}
\hline \multirow{2}{*}{ Ranking* } & \multicolumn{2}{|l|}{ Sumbawa } & \multicolumn{2}{|l|}{ Gunung Kidul } & \multicolumn{2}{|c|}{ South Timor Tengah } \\
\hline & Male & Female & Male & Female & Male & Female \\
\hline 1 & Silviculture & $\begin{array}{l}\text { Timber and non- } \\
\text { timber forest } \\
\text { products' } \\
\text { integrated farm } \\
\text { management }\end{array}$ & Silviculture & - & Silviculture & Silviculture \\
\hline 2 & $\begin{array}{l}\text { Timber and non- } \\
\text { timber forest } \\
\text { products' } \\
\text { integrated farm } \\
\text { management }\end{array}$ & Silviculture & $\begin{array}{l}\text { Timber and } \\
\text { non-timber } \\
\text { forest } \\
\text { products' } \\
\text { integrated } \\
\text { farm } \\
\text { management }\end{array}$ & - & $\begin{array}{l}\text { Timber and } \\
\text { non-timber } \\
\text { forest } \\
\text { products' } \\
\text { integrated } \\
\text { farm } \\
\text { management }\end{array}$ & $\begin{array}{l}\text { Marketing/polici } \\
\text { es on private } \\
\text { forest products' } \\
\text { administration }\end{array}$ \\
\hline 3 & Marketing & Marketing & Marketing & - & Marketing & - \\
\hline 4 & $\begin{array}{l}\text { Introduction to } \\
\text { timber and non- } \\
\text { timber forest } \\
\text { products }\end{array}$ & $\begin{array}{l}\text { Policies on } \\
\text { private forest } \\
\text { products' } \\
\text { administration }\end{array}$ & $\begin{array}{l}\text { Policies on } \\
\text { private forest } \\
\text { products' } \\
\text { administration }\end{array}$ & - & $\begin{array}{l}\text { Policies on } \\
\text { private forest } \\
\text { products' } \\
\text { administration }\end{array}$ & $\begin{array}{l}\text { Timber and non- } \\
\text { timber forest } \\
\text { products' } \\
\text { integrated farm } \\
\text { management }\end{array}$ \\
\hline 5 & $\begin{array}{l}\text { Policies on } \\
\text { private forest } \\
\text { products' } \\
\text { administration }\end{array}$ & $\begin{array}{l}\text { Introduction to } \\
\text { timber and non- } \\
\text { timber forest } \\
\text { products }\end{array}$ & $\begin{array}{l}\text { Extension } \\
\text { communication }\end{array}$ & - & $\begin{array}{l}\text { Extension } \\
\text { communication }\end{array}$ & $\begin{array}{l}\text { Introduction to } \\
\text { timber and non- } \\
\text { timber forest } \\
\text { products }\end{array}$ \\
\hline 6 & $\begin{array}{l}\text { Extension } \\
\text { communication }\end{array}$ & $\begin{array}{l}\text { Extension } \\
\text { communication }\end{array}$ & $\begin{array}{l}\text { Introduction to } \\
\text { timber and } \\
\text { non-timber } \\
\text { forest products }\end{array}$ & - & $\begin{array}{l}\text { Introduction to } \\
\text { timber and } \\
\text { non-timber } \\
\text { forest products }\end{array}$ & $\begin{array}{l}\text { Extension } \\
\text { communication }\end{array}$ \\
\hline
\end{tabular}

Note: * the first rank is the most preferred. Source: Primary data.

Female participants tended to prefer training topics that suited their daily activities. Female farmers in South Timor Tengah who were less likely to work on the farm preferred topics on marketing or privately-owned forest products' management policy and timber trees' cultivation. Female farmers in Sumbawa who usually worked on the farm preferred topics on timber and non-timber forest products' integrated farm management (agroforestry), especially, cultivation of annual crops under stocked stands, such as ginger under teak. In Gunung Kidul, there were no female participants in the training because there were no female forestry extensionists or voluntary extensionists in the district. Furthermore, based on field observations and discussions with farmers, there was a perception that agroforestry and forestry were not the domain of female farmers.

\subsection{Process of agroforestry information dissemination}

\subsubsection{Agroforestry and forestry information sources}

The study showed farmers' sources of information on agroforestry and forestry were obtained from 1) outside the village; 2) inside the village; and 3) electronic and print media. Information sources from outside the village included extensionists, government agencies, NGOs and private agencies. 
Information sources from inside the village included family, friends, neighbours, farmers' groups, and champion farmers. In this study, farmers' sources of information on agroforestry and forestry are shown in a social network diagram (Figure 2). This diagram contains symbols illustrating information sources and lines illustrating dissemination flows and connections among the information sources. Symbols used in the study are circle, triangle and square. The size of the symbol shows the role and influence of the information sources to farmers. The bigger the symbol, the greater the roles and influences.

The most important and influential sources of information on agroforestry and forestry for farmers in the three districts were sourced from outside their villages, that is, extensionists, district forestry agencies, NGOs and forestry projects. The most important and influential sources of information from inside their villages were family, farmers' groups and champion farmers.

From a gender perspective, there were differences in sources of information that served as a reference for each gender to obtain agroforestry and forestry information. The most influential sources of information for female farmers were family, farmers' groups and NGOs whereas the most influential sources of information for male farmers were extension workers, district forestry agencies and NGOs (Figure 2). Information sources for female farmers tended to come from inside the village whereas for male farmers they were from outside. This tendency was owing to male farmers being more likely to have opportunities to engage with outsiders than female farmers. For example, male farmers had a higher tendency to be assigned to attend training and extension events outside the village, for instance, at district, provincial and national levels. Female farmers had relatively fewer opportunities to attend training taking place outside the village. Thus, female farmers tended to depend on family, farmers' groups and champion farmers who attended the training. The tendency for female farmers to access information through electronic media was greater than male farmers since they tended to stay at home watching television.

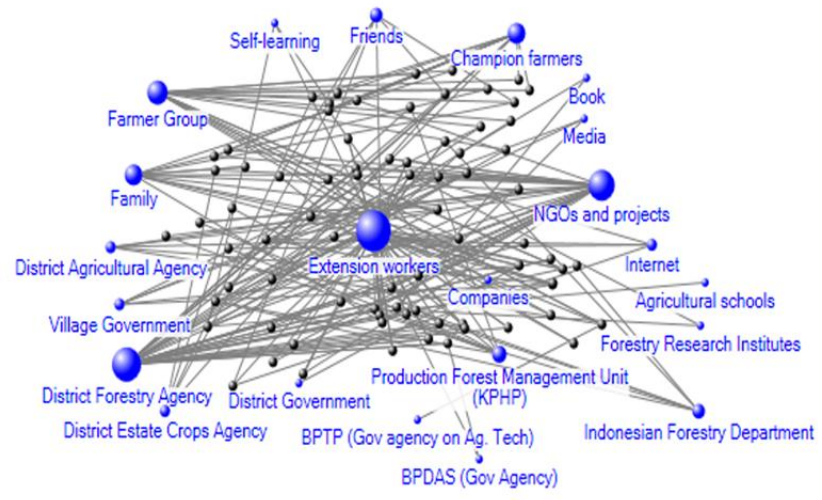

Sources of information for male

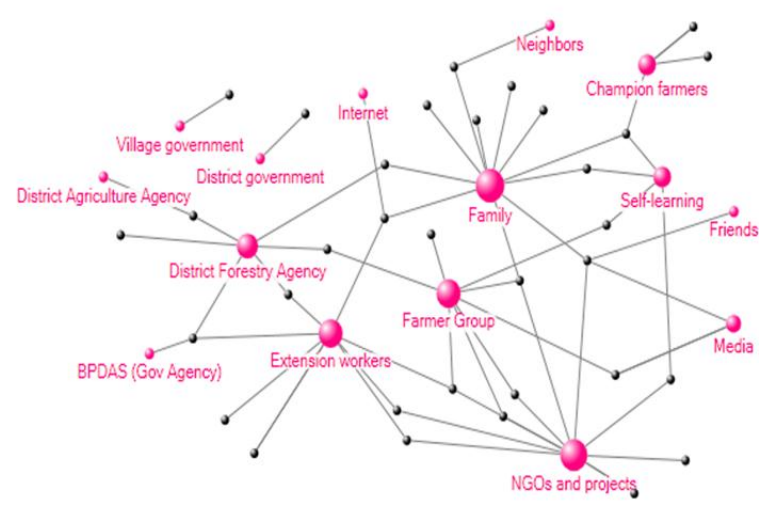

Sources of information for female

Figure 2. Networks of information sources in all studied districts, by gender 
The differences in priorities of agroforestry and forestry sources of information were also found between districts (Figure 3). In Gunung Kidul, extension workers, district forestry agency and NGOs were the primary sources. In Sumbawa, champion farmers, NGOs, KPHP (Production Forest Management Unit), and extension workers were most frequently accessed by farmers. In South Timor Tengah, extension workers, farmers' groups and family were the primary sources. In South Timor Tengah, farmers' limited access to information from outside their villages led to dependency on information from inside villages, such as from farmers' groups and family. Both played important roles in the dissemination of agroforestry and forestry information. In Gunung Kidul, families were not considered as sources of information.

The number of sources of information in Gunung Kidul was higher than in Sumbawa and South Timor Tengah. It was also found that only in Gunung Kidul was the Ministry of Forestry a source. South Timor Tengah had the least number of sources of information because of the limited number of organizations focusing on agroforestry and forestry compared to Gunung Kidul and Sumbawa.

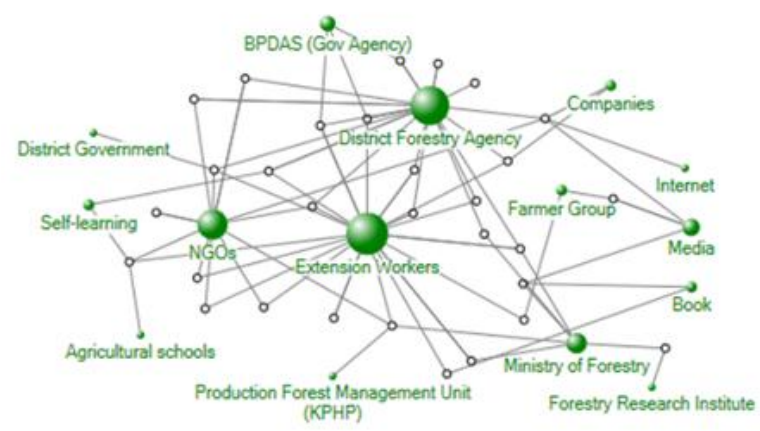

Gunung Kidul District

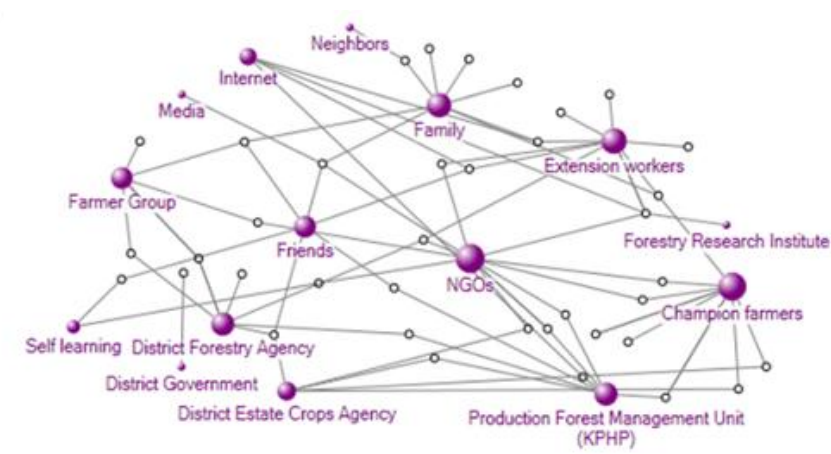

Sumbawa District

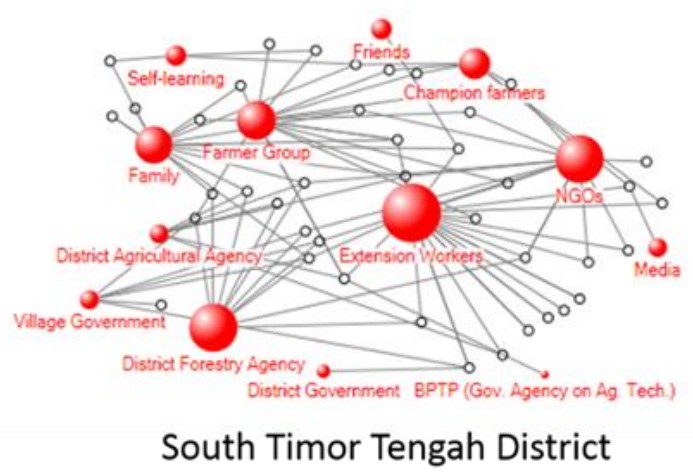

Figure 3. Variations in priorities of sources of information on agroforestry and forestry in Gunung Kidul, Sumbawa and South Timor Tengah Districts

\subsubsection{Agroforestry and forestry information sources for farmers by gender in Gunung Kidul}

In Gunung Kidul, agroforestry and forestry extension or training were more prioritized for men; only a handful of women with important roles in the community, such as the female leader of a farmers' group and a village head, were invited to participate in training. There was a perspective in the community that agroforestry and forestry activities were the domain of men, thus, women were less 
active in searching for information related to the subjects. This led to less sources of information used by women.

Both for men and women, extension workers and NGOs were the primary sources of agroforestry and forestry information (Figure 4.). The differing priorities for sources of information between men and women in Gunung Kidul was owing to farmers' groups and media proving more attractive for women whereas programs from the Ministry of Forestry served as sources of agroforestry information for men. Male farmers in Gunung Kidul had greater access to sources of information at district and national levels compared to female farmers. Easy access to national sources of information was the privilege only of several farmers who acted as voluntary extensionists. As a form of capacity development, voluntary extensionists were assigned to attend training at national level.
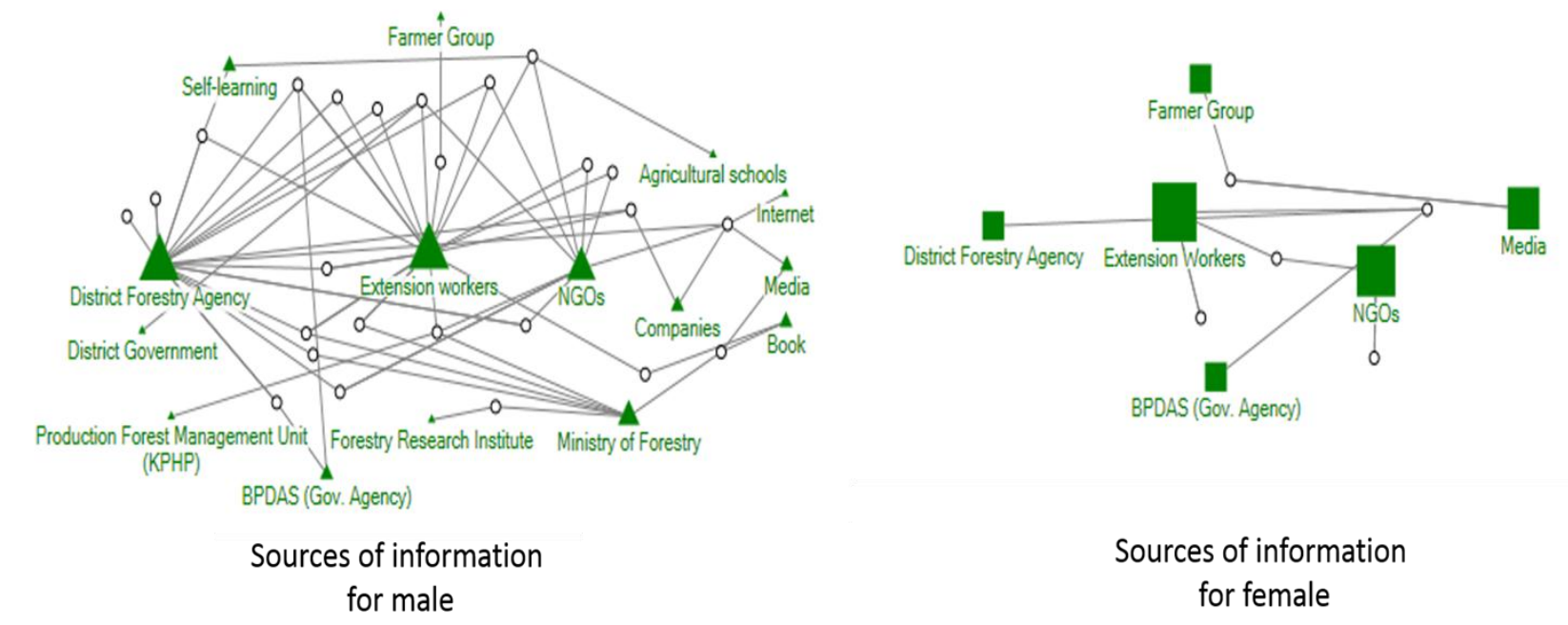

Figure 4. Networks of information sources for male and female farmers and voluntary extension workers in Gunung Kidul

\subsubsection{Agroforestry and forestry information sources for farmers by gender in Sumbawa}

Farmers in Sumbawa received agroforestry and forestry information from outside and inside their villages in balance. NGOs, extension workers, forestry agency officers and production forest management unit staff of Batulanteh were important sources of information from outside the villages while inside were champion farmers, family, farmers' groups and friends. Farmers in Sumbawa had limited access to information from electronic media and internet owing to poor facilities and infrastructure. The balanced nature of information sources was influenced by proximity of the villages to the district capital. Extension workers, forestry agency officers and NGOs could gain easy access. Interpersonal communication with family, farmers' groups and neighbours was an effective form of information dissemination.

Information sources of significance to female farmers in Sumbawa were inside the villages, that is, family, champion farmers, farmers' groups, neighbours and friends (Figure 5). Family was the most important source, followed by champion farmers and farmers' groups while the important and more 
influential information sources from outside the village for female farmers were NGOs rather than extension workers or governmental agencies.

Information sources from outside and inside the village held equal weight for male farmers in Sumbawa. The most significant from outside the village were extension workers, NGOs and the production forest management unit of Batulanteh. Significant sources from inside the village were champion farmers, f'rmers' groups and friends. The study showed that female farmers tended to make more use of the internet and electronic media compared to male farmers.
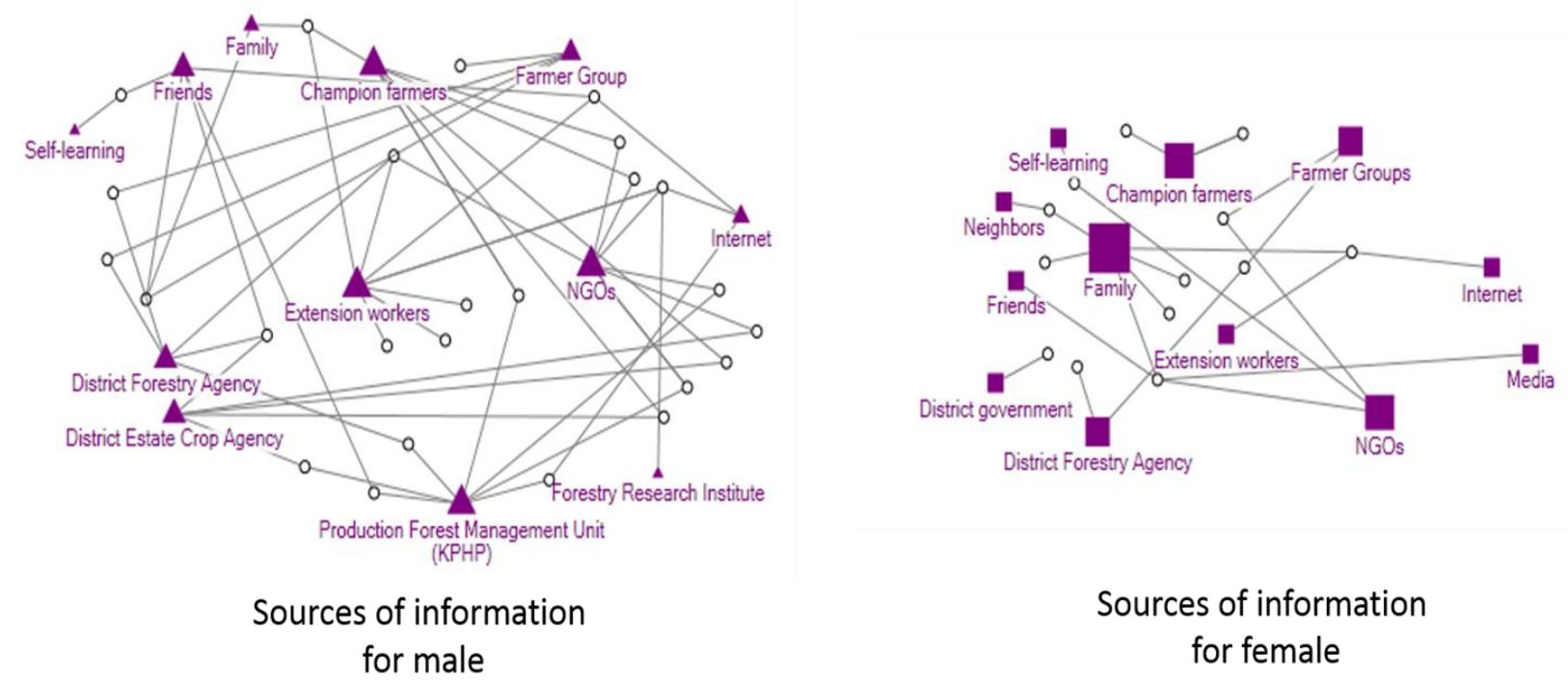

Figure 5. Networks of information sources for male and female farmers and voluntary extension workers in Sumbawa

\subsubsection{Agroforestry and forestry information sources for farmers by gender in South Timor}

\section{Tengah}

In South Timor Tengah, extension workers played a significant role as sources of information for farmers, followed by family and farmers' groups especially when farmers had minimal interaction with extension workers. Bosen and Ajobaki villages shared the same issue owing to their remote locations, leading to limited visits by extension workers.

Sources of information acquired from inside the villages, that is, family and farmers' groups, had more significant influence on female farmers in South Timor Tengah compared to sources acquired from outside (Figure 6). Aside from those two sources, female farmers accessed information from their village governments and champion farmers while sources from outside the village for female farmers were extension workers, forestry agency and NGOs, all sharing equal weight. Opportunities for female farmers to take part in training and extension activities were unequal, particularly for those living in remote areas.

Male farmers in South Timor Tengah tended to receive agroforestry and forestry information from outside their villages although sources inside the villages — such as family and farmers' groups also played significant roles. Extension workers were the most influential sources of information for 
male farmers because male farmers often had more opportunities to take part in extension activity in their village or outside.
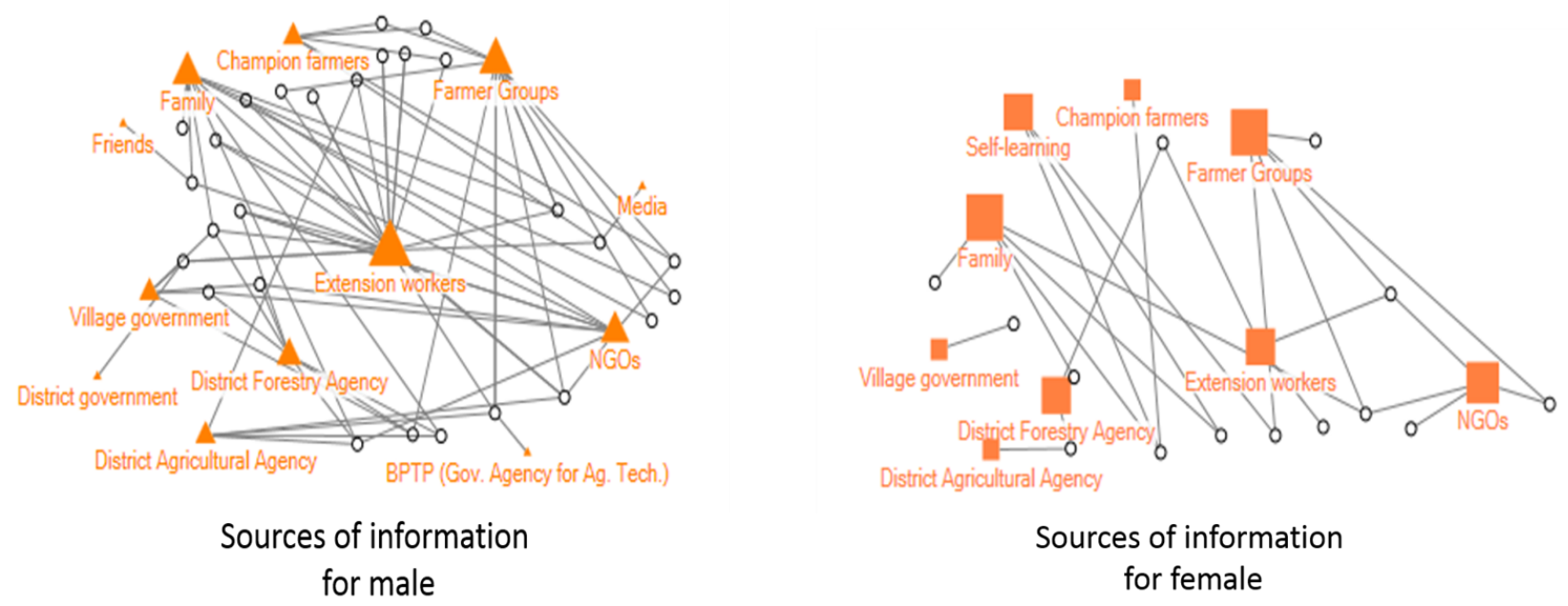

Figure 6. Networks of information sources on agroforestry and forestry for male and female farmers in South Timor Tengah

\subsubsection{Agroforestry and forestry information dissemination as a result of training held by KANOPPI}

The dissemination of information was analyzed based on agroforestry and forestry extension topics received by farmers, namely, 1) timber and non-timber forest products; 2) timber and non-timber forest products' marketing; 3) policies on administration of forest products on private land; 4) silviculture; and 5) agroforestry farm management. Analysis was also conducted of answers acquired from non-training-participant respondents, especially, regarding the information sources that they had accessed previously on the same topics.

\subsubsection{Information dissemination about timber and non-timber forest products}

The forestry agency was the most important disseminator compared to others regarding timber and non-timber forest products, especially, the definitions and types of products. Information disseminated from KANOPPI activities was mostly received by farmers through the forestry agency (Figure 7), thus, in future, extension or training activities disseminating information should formally involve district forestry agency staff as participants. This would support information dissemination through extension and training to farmers requiring such information. 


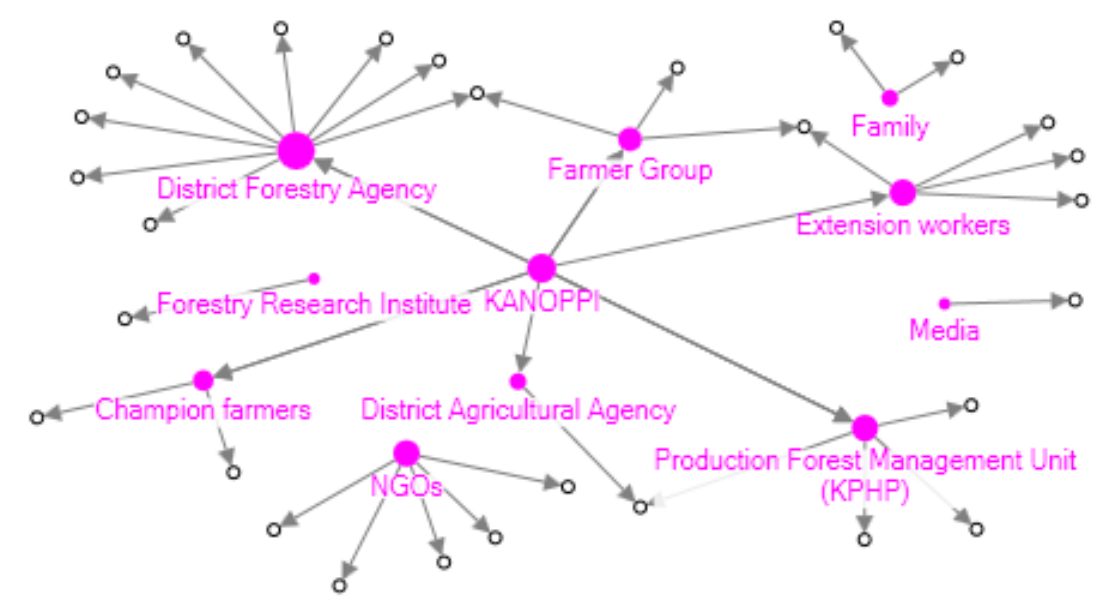

Figure 7. Network of farmers' information sources on timber and non-timber forest products

\subsubsection{Information dissemination about marketing timber and non-timber forest products}

For marketing timber and non-timber forest products, KANOPPI provided information on how to market timber, the desirable qualitites demanded by the markets, as well as prices for products of varying quality. Information delivered by KANOPPI was received by non-participating farmers, especially from timber and non-timber products' traders involved in the training. Figure 8 shows that extension or training aimed at improving farmers' knowledge of timber and non-timber products' marketing should involve traders because they have high potential as information disseminators. For traders, providing extension services to farmers could serve as a strategy to produce favourable quality timber and non-timber products.

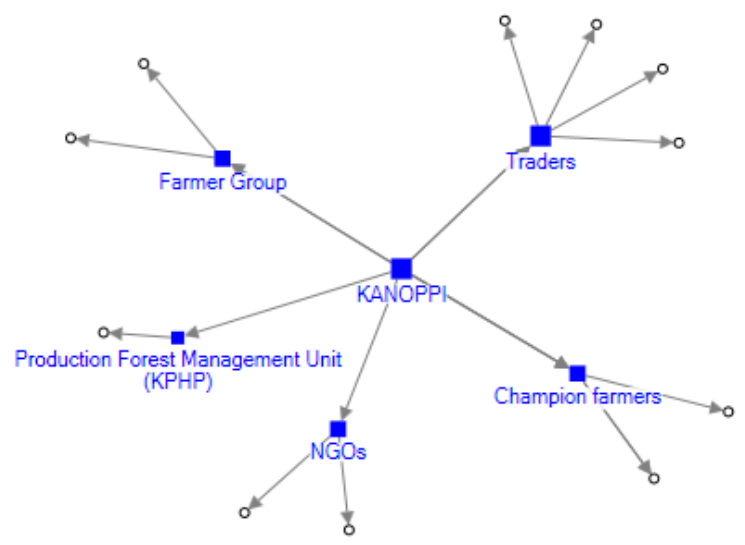

Figure 8. Network of farmers' information sources on marketing of timber and non-timber forest products

\subsubsection{Information dissemination about policies regarding administration of forest products produced on private land}

Information about policies related to administration (licensing) of forest products on private land was disseminated by KANOPPI through training and received by non-training-participant respondents 
through the village governments, specifically, the village heads and staff (Figure 9). Village governments play a significant role in granting permits to harvest and trade timber from privately owned land. Thus, in the promotion of policies on forest product management on private land, village governments should be engaged as information disseminators.

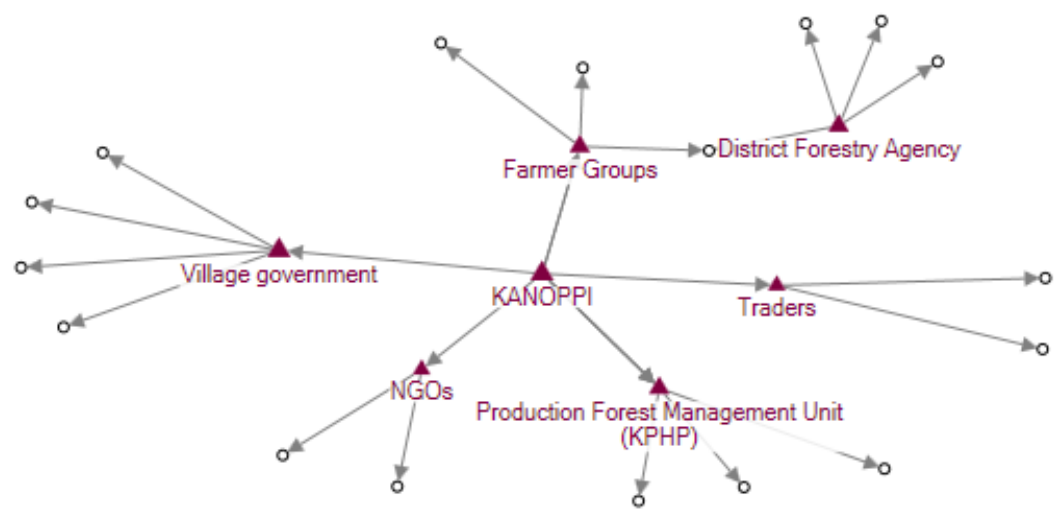

Figure 9. Farmers' information sources network on policy on the administration of forest products on private land

\subsubsection{Dissemination of information about silviculture}

Silvicultural topics discussed at the training organized by KANOPPI were thinning and pruning of tree crops, particularly, teak. Information dissemination through the KANOPPI training in timber and non-timber forest products was received by non-participant respondents mostly from the forestry agency and extension workers. Figure 10 shows that it is important to invite forestry agency officers and extension workers as training participants on topics related to silviculture because they disseminate useful information to farmers about improving timber quality.

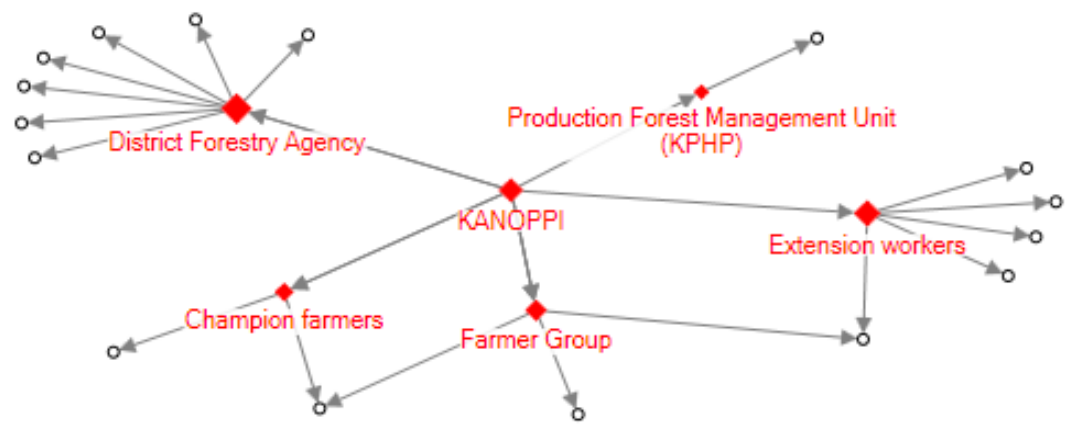

Figure 10. Sources of information about silviculture topics

\subsubsection{Dissemination of information about agroforestry farm management}

Information about agroforestry farm management delivered by KANOPPI focused on planting of annual crops with economic value under timber trees, for example, ginger beneath teak. Information such as appropriate spacing, required shade percentage, and annual crop varieties that could be grown beneath a teak canopy were delivered in the training. Non-participant respondents received the information delivered by KANOPPI from forestry agency officers and extension workers (Figure 11). 
Therefore, similar to the strategy for disseminating silvicultural information, dissemination of information on agroforestry farm management should involve district forestry agency officers and extension workers.

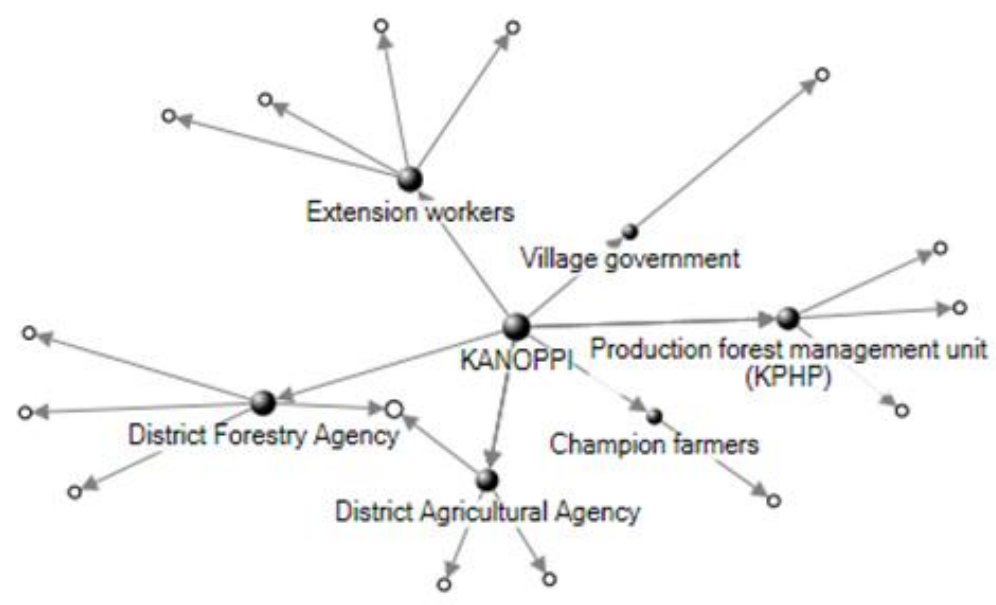

Figure 11. Network of sources of information about agroforestry farm management

\subsection{Relation between sources of information, information topic and adoption process}

A knowledge adoption process starts with successful dissemination to an audience, in this case, farmers. After understanding information about new technologies, farmers usually conduct trials. If the new technology is found to be beneficial, it will be applied on the farm. We found that farmers' responses to new technologies varied depending on the source of information and whether the information was relevant.

Stages of the adoption were strongly influenced by the reliability of the source of information (Figure 12). Both the first, assessing relative advantage, and the second, conducting trials, were influenced by the reliability of the source of information and the appropriateness of the technology. In the third, adoption, stage, the most influential factor was the simplicity of the technology. Thus, aside from the reliability of the source of information, attention should be paid to the type of information provided to ensure it meets the needs of the farmers. 


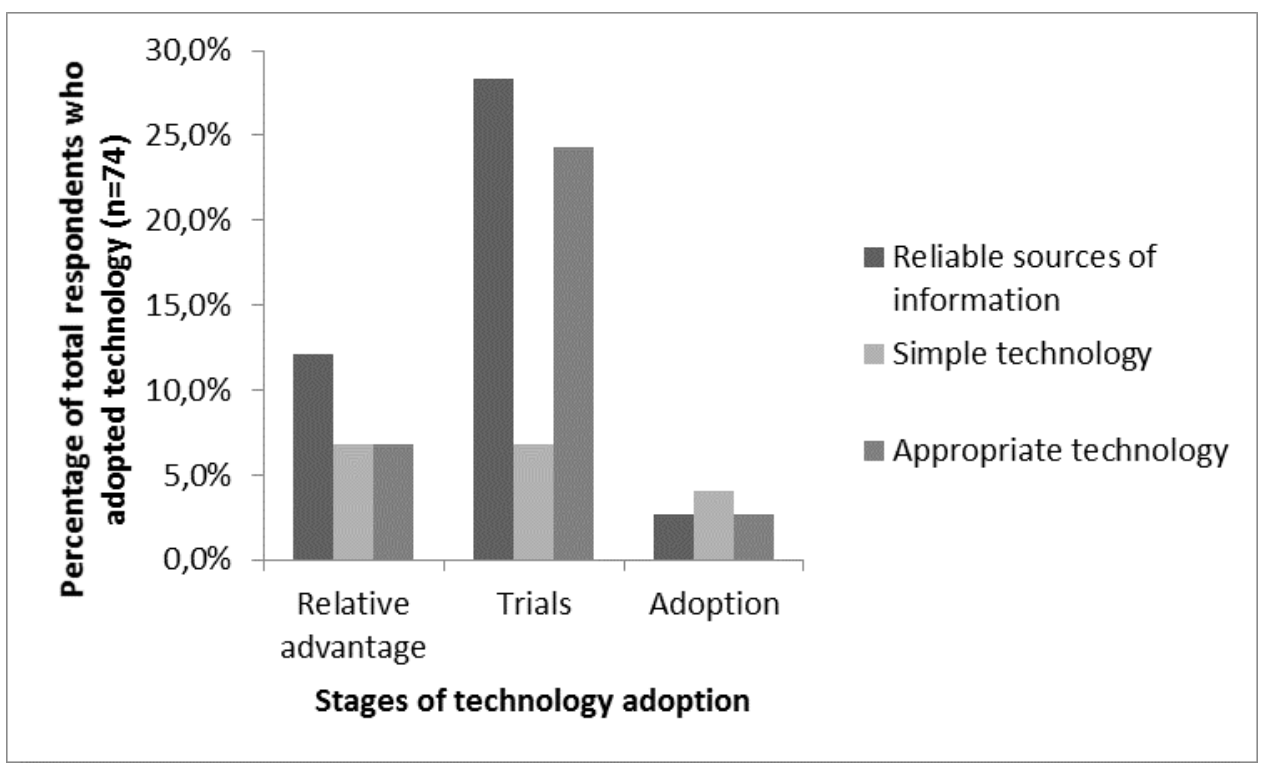

Figure 12. Farmers' perceptions of factors affecting the adoption of agroforestry technology

\subsection{Developing agroforestry training or extension services based on farmers' needs}

Information regarding farmers' preferences for extension topics and information dissemination can be used as the basis for developing agroforestry training or extension based on farmers' needs. In addition, evaluation by participants of the training can be used to design further training or extension services. In this study, training and extension evaluations were conducted based on the criteria of training participant, method of extension used, material presented, resource person, and duration of activity.

\subsubsection{Participants in agroforestry training}

Each participant's experience in training and extension was an important consideration when conducting training and extension. Participants were people who met criteria associated with the topic. The selection of participants involved people at the target sites providing a range of criteria, taking into consideration the local need for training and extension. Participants selected were champion or experienced farmers, members of farmers' groups, farmers with motivation and willingness to disseminate knowledge, public figures, women and literate younger farmers (Figure 13). Participants from farmers' groups are able to assist in monitoring and evaluation after training and wider dissemination of the acquired information to other members of the group was almost guaranteed. Participants were also selected from members of farmers' groups who had never received any training. Non-participating farmers were also selected as a control. 


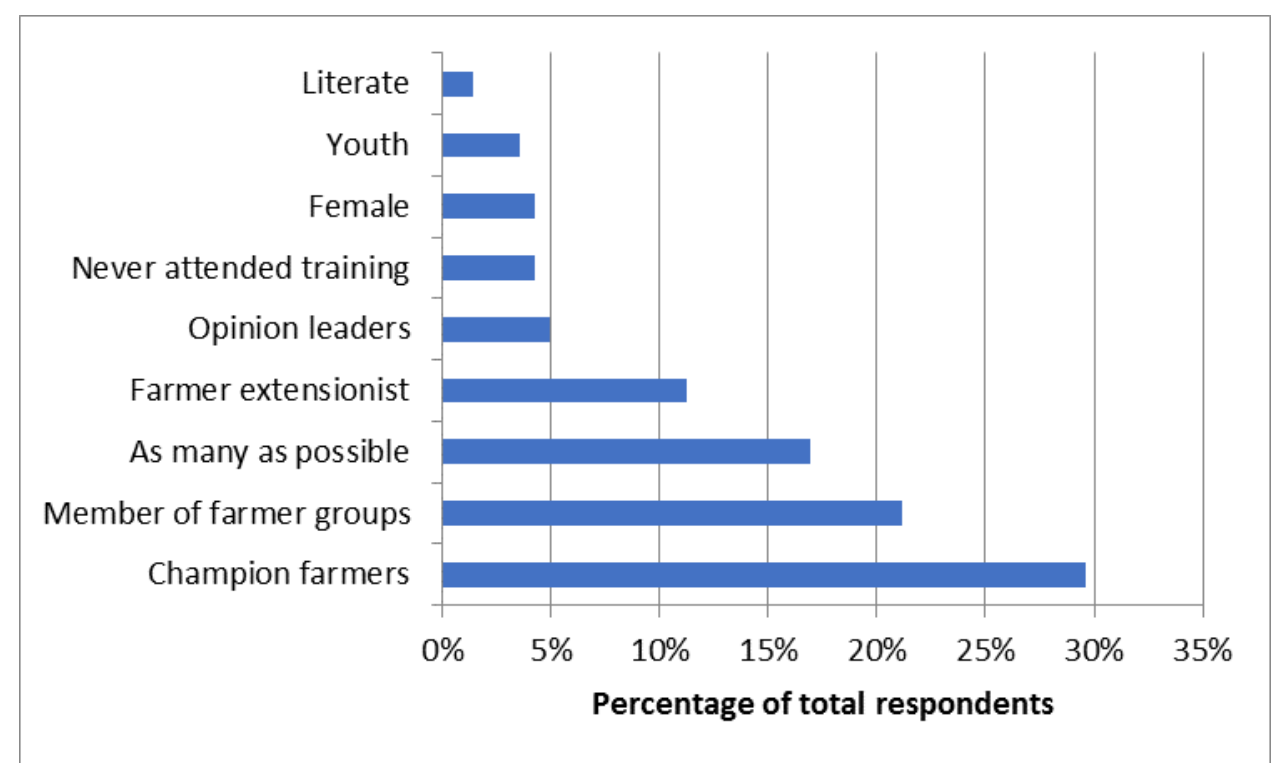

Figure 13. Criteria for selecting training and extension participants based on respondents' inputs

\subsubsection{Methods used in agroforestry training}

Methods of extension or training conducted by KANOPPI were a combination of discussions, practice and field visits. Based on all respondents' feedback, the most favourable method was a combination of discussion and practice, next was practice only, and third was a combination of discussion, practice and field visits (Figure 14). Respondents' least favoured method was discussion only, next a combination of practice and field visits, field visit only, and discussion and field visits.

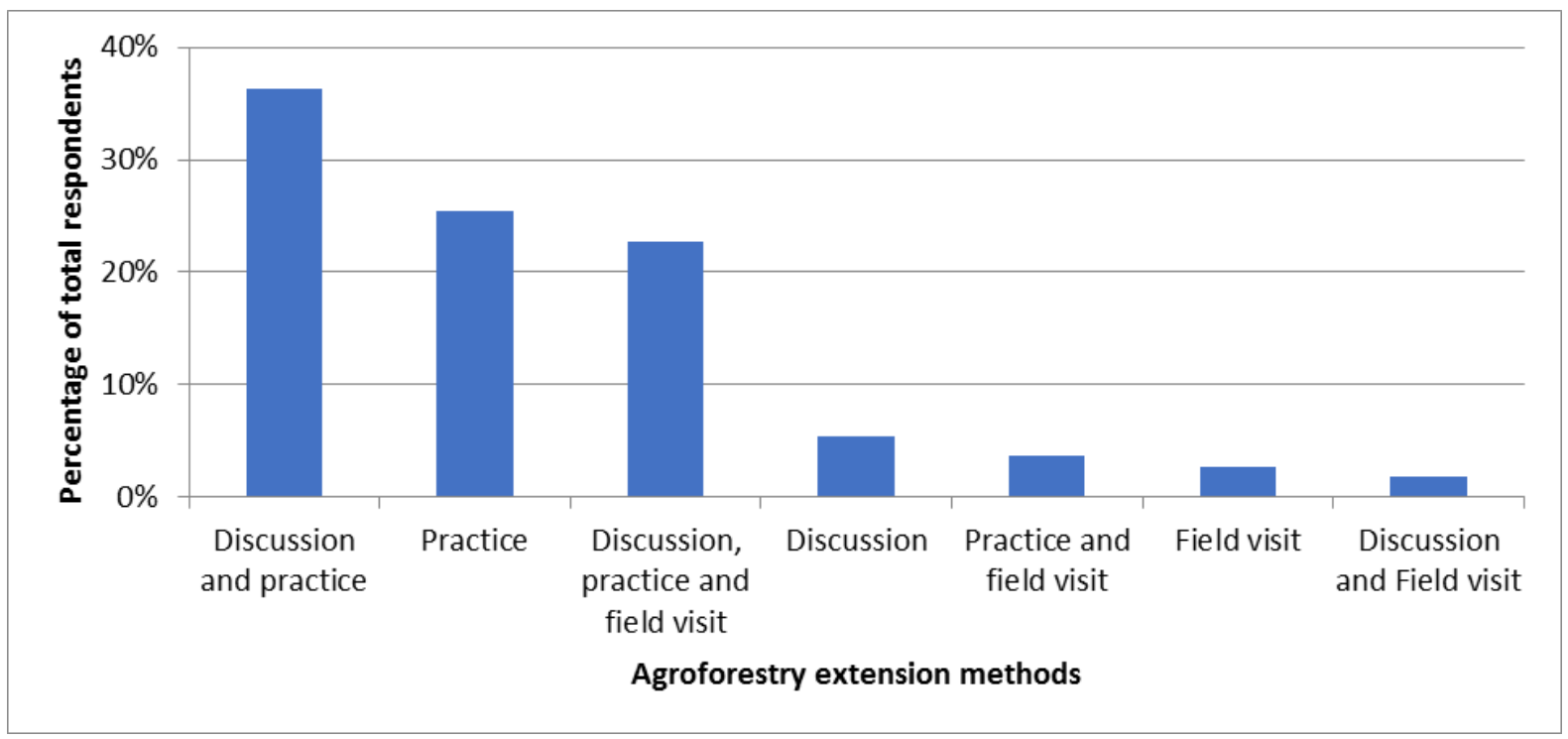

Figure 14. Respondents' preferred methods for agroforestry training or extension

Based on previous agroforestry training held by KANOPPI, the combination of discussion and practice eases participants into learning new knowledge and technologies. Discussions were held to introduce theory and were combined with farmers' daily experience and practice to improve participants' skills in newly learned techniques. Field visits were held to build participants' 
motivation and insight into the topics. During field visits, participants were able to see successful practices conducted by farmers or others, which provided motivation to implement the practices themselves and disseminate the knowledge and technologies learned in the training.

\subsubsection{Material presented in agroforestry training}

Sixty-one per cent $(61 \%)$ of participants stated that the material provide was sufficient to provide insight on timber and non-timber forest products. Five per cent (5\%) of participants stated that there was too much material covered in a short amount of time. Some participants suggested that the material should have been focused on specific subjects, such as marketing, non-timber forest products, policies regarding forest product management on private land, silviculture, agroforestry management, extension, and forest conservation. Respondents suggested to deepen the marketing topic, including 1) providing market information about timber and non-timber forest products; and 2) increasing the value of non-timber forest products. Topics regarding non-timber forest products that needed to be revisited if there was to be further training were bee farms for honey production, white ginger, 'tarum' (Indigofera sp) and bamboo.

Respondents who never participated in training said that they needed information on silvicultural techniques (tree pruning and thinning), non-timber forest products, alternate crop and fruit-crop cultivation, agroforestry products' marketing, agroforestry farm management and forest conservation.

Generally, silviculture and non-timber forest products' marketing topics were the most demanded topics in all three districts.

\subsubsection{Timing and duration of agroforestry training}

Training and extension must consider timing and duration in order to not interrupt important events, such as cultivation, harvesting, and religious/cultural activities. Timing and duration affected the effectiveness of the training and the number of participants. The four-day duration of training held by KANOPPI was considered sufficient by $50.9 \%$ participants, however, $35 \%$ participants suggested to add another day, and $7 \%$ suggested to reduce the number of days.

The four-day duration was considered sufficient by both men and women. However, male farmers preferred to add a day whereas female farmers preferred to reduce the number of days (Figure 15). Female farmers tended to have little flexible time because of domestic and farming commitments, compared to male farmers. Female farmers had limited time for attending training outside their village if it was conducted over four days or more. Some respondents also suggested to hold regular meetings, for example, once a week, to provide agroforestry training to farmers. 


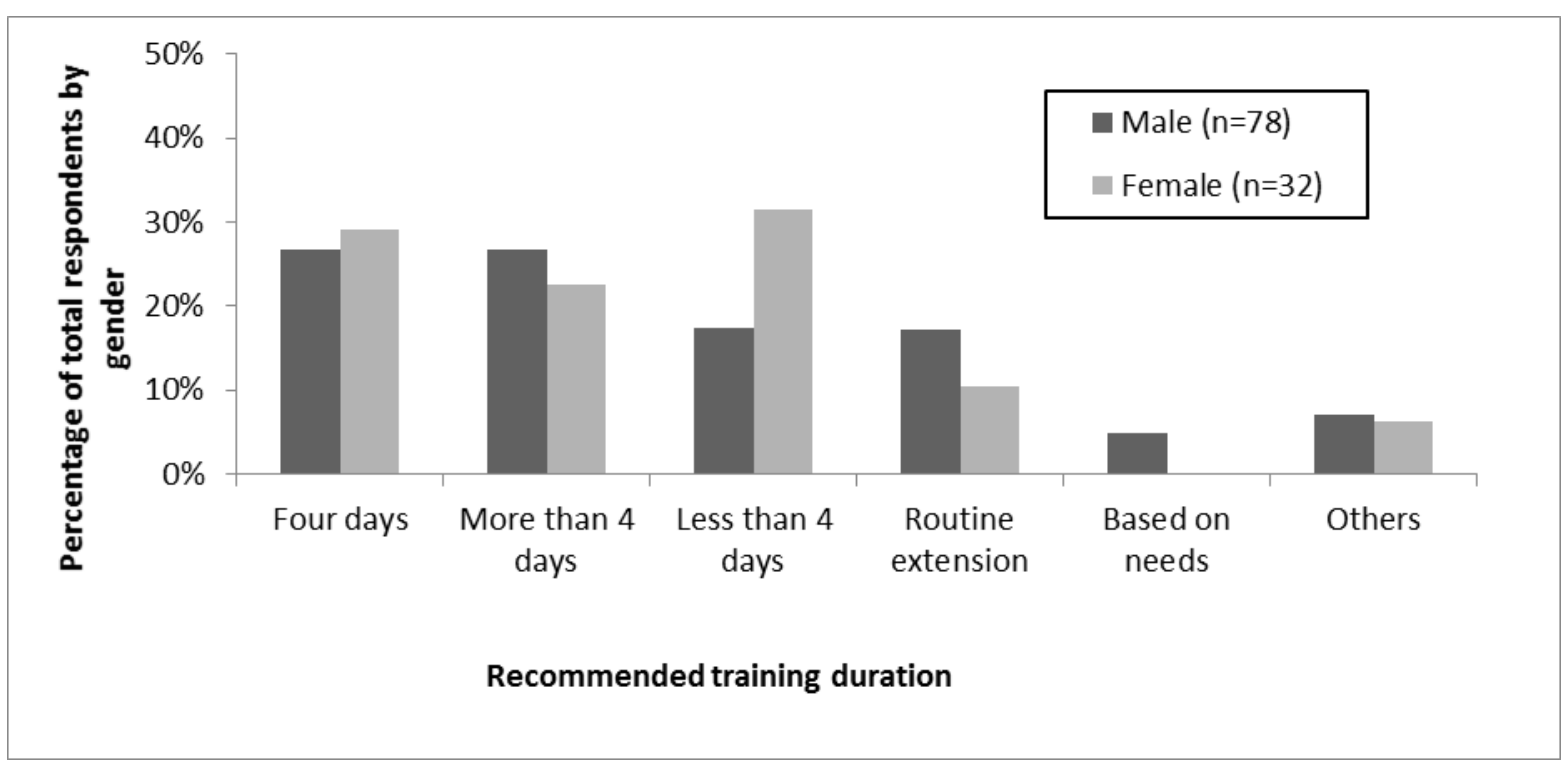

Figure 15. Recommended duration of training or extension for both male and female participants

\section{Conclusion and recommendations}

\section{Conclusion}

Farmers in Gunung Kidul, Sumbawa and South Timor Tengah preferred practical and basic extension topics, such as silviculture, agroforestry farm management, timber and non-timber products' marketing. Interest in a training topic usually depended on farmers' habits in specific locations and on gender.

Information dissemination by farmers who attended training to other farmers took different forms depending on location, gender and available sources of information. Generally, extensionists played important roles in agroforestry and forestry information dissemination to farmers. In addition, forestry agency and NGOs were also important actors in dissemination. The role of farmers' groups, family, champion farmers and NGOs were crucial in information dissemination, especially, for female farmers.

\section{Recommendations}

The form of agroforestry and forestry training or extension should be adjusted to farmers' requirements and local conditions. The form of training or extension should be conducted with regard to topic, participants, method, timing and duration. Silviculture, agroforestry farm management and marketing were the most proposed topics from farmers. The selection of participants for training should consider each farmer's background, such as: 1) member of a farmers' group, recommended by their peers; 2) farmers with motivation and willingness to disseminate information; and 3) 
experienced farmers. Several groups might be involved in the training or extension, such as, 1) traders in the timber and non-timber products' marketing topic; 2) extensionists and officers of forestry agencies in the forestry and agroforestry topic; and 3) village government officials for permits related to timber trading management and utilization. Methods can take the form of a combination of discussion, practice and field visits to increase knowledge, skills and motivation.

In each location, farmers had particular preferences for topics as well as the information dissemination process. To support the dissemination of information about agroforestry and forestry to farmers most in need, it would be necessary to analyze the actors who play important roles in dissemination and their level of education, before undertaking any training or extension activities. 


\section{Reference}

De Foresta A, Kusworo, Michon G, Djatmiko WA. 2000. Ketika kebun berupa hutan: Agroforest khas Indonesia: Sumbangan masyarakat bagi pembangunan berkelanjutan. Bogor, Indonesia: International Centre for Research in Agroforestry; Paris, France: Institut de Recherche pour le Développement; Jakarta, Indonesia: Ford Foundation.

Putro DW, Nawir AA, Rida Hakim M, Syafii S, Julmansyah, Muktasam. 2015. Laporan penelitian analisis kebijakan dalam mendukung produksi, pemasaran dan pengolahan hasil hutan kayu dan hasil hutan bukan kayu di Kabupeten Sumbawa, Nusa Tenggara Barat. Bogor, Indonesia: WWF Indonesia; Mataram, Indonesia: Universitas Mataram.

Hairiah K, Sardjono MA, Sabarnurdin S. 2003. Bahan ajar 1: pengantar agroforestri. Bogor, Indonesia: World Agroforestry Centre (ICRAF) Southeast Asia Regional Office.

Nair PKR. 1993. An introduction to agroforestru. Dordrecht, Netherlands: Kluwer Academic Publishers.

Riyandoko, Martini E, Perdana A, Yumn A, Roshetko JM. 2016a. Existing conditions, challenges and needs in the implementation of forestry and agroforestry extension in Indonesia. Working Paper 238. Bogor, Indonesia: World Agroforestry Centre (ICRAF) Southeast Asia Regional Program. DOI: http://dx.doi.org/10.5716/WP16141.PDF

Riyandoko, Syafii S, Abdulrahman M, Widhiana W, Junaidin, Setyawan A, Danayasa P, Sumardamto P, Joko Purwanto MT. 2016b. Panduan pelatihan penyuluh swadaya dan petani unggul sebagai pendekatan penyuluhan agroforestri. Bogor, Indonesia: World Agroforestry Centre (ICRAF) Southeast Asia Regional Program. 
Appendix 1. Syllabus training for voluntary extension and champion farmers on timber and non-timber forest product production and marketing strategies

\begin{tabular}{|c|c|c|c|c|c|c|}
\hline No. & Topic & Subjects & Goals & Methods & Instrument & Time \\
\hline 1 & Group dynamics & $\begin{array}{l}\text { Introduction, ice breaking } \\
\text { Identification of participants' } \\
\text { expectations } \\
\text { Building agreement } \\
\text { Learning contract }\end{array}$ & $\begin{array}{l}\text { Getting to know each other } \\
\text { Recognition of participants' expectations of the } \\
\text { training activity } \\
\text { Agreement on the agenda and training rules }\end{array}$ & $\begin{array}{l}\text { Games } \\
\text { Discussion } \\
\text { Brainstorming }\end{array}$ & $\begin{array}{l}\text { Flipchart, marker, } \\
\text { metaplan paper }\end{array}$ & $\begin{array}{l}60 \\
\text { minutes }\end{array}$ \\
\hline 2 & $\begin{array}{l}\text { Pretest for } \\
\text { participants }\end{array}$ & Rapid self-assessment & $\begin{array}{l}\text { Identification of the participants' knowledge and } \\
\text { background of the training topic }\end{array}$ & $\begin{array}{l}\text { Completing the rapid } \\
\text { self-assessment form }\end{array}$ & $\begin{array}{l}\text { A rapid self-assessment } \\
\text { form copied on a plano } \\
\text { paper. }\end{array}$ & $\begin{array}{l}30 \\
\text { minutes }\end{array}$ \\
\hline 3 & $\begin{array}{l}\text { Introduction to } \\
\text { timber and non- } \\
\text { timber forest } \\
\text { products for } \\
\text { farmers' } \\
\text { livelihoods and the } \\
\text { environment }\end{array}$ & $\begin{array}{l}\text { Definition of forest products: } \\
\text { timber, non-timber } \\
\text { Categorization of non-timber } \\
\text { products (refer to } \\
\text { Regulations of the Minister } \\
\text { of Forestry No. 35/2007) } \\
\text { Local timber and non-timber } \\
\text { products }\end{array}$ & $\begin{array}{l}\text { Participants understand products: timber and } \\
\text { non-timber } \\
\text { Participants can identify and categorize local } \\
\text { timber and non-timber products }\end{array}$ & $\begin{array}{l}\text { Presentation } \\
\text { Discussion } \\
\text { Simulation/games }\end{array}$ & $\begin{array}{l}\text { LCD projector, computer, } \\
\text { marker, metaplan paper, } \\
\text { whiteboard }\end{array}$ & $\begin{array}{l}60 \\
\text { minutes }\end{array}$ \\
\hline 4 & $\begin{array}{l}\text { Policies on timber } \\
\text { and non-timber } \\
\text { products }\end{array}$ & $\begin{array}{l}\text { Policies related to timber } \\
\text { Policies related to non- } \\
\text { timber }\end{array}$ & $\begin{array}{l}\text { Participants understand policies related to timber } \\
\text { and non-timber products }\end{array}$ & $\begin{array}{l}\text { Presentation } \\
\text { Role play }\end{array}$ & $\begin{array}{l}\text { LCD projector, computer, } \\
\text { marker, metaplan paper, } \\
\text { plano paper, whiteboard }\end{array}$ & $\begin{array}{l}120 \\
\text { minutes }\end{array}$ \\
\hline 5 & $\begin{array}{l}\text { Introduction to } \\
\text { timber and non- } \\
\text { timber products' } \\
\text { marketing }\end{array}$ & $\begin{array}{l}\text { Exploration of local timber } \\
\text { and non-timber products' } \\
\text { markets } \\
\text { Visit to processor and/or } \\
\text { buyer of timber and non- } \\
\text { timber products }\end{array}$ & $\begin{array}{l}\text { Participants can assess the featured local timber } \\
\text { and non-timber products } \\
\text { Participants can determine timber and non- } \\
\text { timber products' markets } \\
\text { Participants understand the timber marketing } \\
\text { chain }\end{array}$ & $\begin{array}{l}\text { Group discussion } \\
\text { Visits to sawmill and } \\
\text { non-timber products' } \\
\text { processing facilities }\end{array}$ & $\begin{array}{l}\text { Stationery, plano paper, } \\
\text { marker }\end{array}$ & $\begin{array}{l}180 \\
\text { minutes }\end{array}$ \\
\hline 6 & Tree measurement & $\begin{array}{l}\text { Introduction to tree } \\
\text { measurement using various } \\
\text { methods }\end{array}$ & $\begin{array}{l}\text { Participants understand tree measurement using } \\
\text { various methods } \\
\text { Participants understand the tools used in tree }\end{array}$ & $\begin{array}{l}\text { Presentation } \\
\text { Brainstorming }\end{array}$ & $\begin{array}{l}\text { LCD projector, computer, } \\
\text { marker, metaplan paper, } \\
\text { whiteboard }\end{array}$ & $\begin{array}{l}120 \\
\text { minutes }\end{array}$ \\
\hline
\end{tabular}




\begin{tabular}{|c|c|c|c|c|c|c|}
\hline No. & Topic & Subjects & Goals & Methods & Instrument & Time \\
\hline 7 & $\begin{array}{l}\text { Tree measurement } \\
\text { practice and } \\
\text { simple timber } \\
\text { volume calculation }\end{array}$ & $\begin{array}{l}\text { Tree measurement using } \\
\text { various methods, such as } \\
\text { Master Tree Grower }\end{array}$ & $\begin{array}{l}\text { Participants can carry out tree measurement to } \\
\text { determine timber volume using various methods }\end{array}$ & $\begin{array}{l}\text { Presentation } \\
\text { Measurement } \\
\text { practice/training on farm } \\
\text { Result of presentation } \\
\text { and discussion }\end{array}$ & $\begin{array}{l}\text { Whiteboard/flipcard, } \\
\text { marker, paper } \\
\text { Measurement tape and } \\
\text { timber measuring tools }\end{array}$ & $\begin{array}{l}180 \\
\text { minutes }\end{array}$ \\
\hline 8 & $\begin{array}{l}\text { Maintenance of } \\
\text { plants or } \\
\text { silviculture }\end{array}$ & $\begin{array}{l}\text { Planting, thinning, pruning } \\
\text { and harvesting procedures }\end{array}$ & $\begin{array}{l}\text { Participants understand crop cultivation } \\
\text { management (silviculture) }\end{array}$ & $\begin{array}{l}\text { Lecture } \\
\text { Brainstorming } \\
\text { Games/simulations }\end{array}$ & $\begin{array}{l}\text { LCD projector, computer, } \\
\text { marker, metaplan paper, } \\
\text { plano paper }\end{array}$ & $\begin{array}{l}60 \\
\text { minutes }\end{array}$ \\
\hline 9 & $\begin{array}{l}\text { Observation of } \\
\text { silviculture on farm }\end{array}$ & $\begin{array}{l}\text { Practice/simulation of } \\
\text { pruning and thinning } \\
\text { Observation of growth and } \\
\text { crop cultivation } \\
\text { management }\end{array}$ & $\begin{array}{l}\text { Participants understand pruning and thinning } \\
\text { teak } \\
\text { Participants compare silvicultural treatments on } \\
\text { farm }\end{array}$ & $\begin{array}{l}\text { Practice/simulation } \\
\text { Observation } \\
\text { Presentation } \\
\text { Discussion }\end{array}$ & $\begin{array}{l}\text { Flipchart, marker, } \\
\text { metaplan paper, plano } \\
\text { paper, paper tape, hvs } \\
\text { paper }\end{array}$ & $\begin{array}{l}180 \\
\text { minutes }\end{array}$ \\
\hline 10 & $\begin{array}{l}\text { Integrated } \\
\text { management of } \\
\text { various timber and } \\
\text { non-timber } \\
\text { products }\end{array}$ & $\begin{array}{l}\text { Alternative timber and non- } \\
\text { timber integrated farm } \\
\text { management } \\
\text { Agroforestry } \\
\text { Silvopasture } \\
\text { Agrosilvofishery }\end{array}$ & $\begin{array}{l}\text { Participants understand different types of timber } \\
\text { and non-timber integrated agroforestry } \\
\text { management }\end{array}$ & $\begin{array}{l}\text { Presentation } \\
\text { Discussion } \\
\text { Brainstorming }\end{array}$ & $\begin{array}{l}\text { LCD projector, computer, } \\
\text { marker, metaplan paper, } \\
\text { plano paper, paper tape, } \\
\text { hvs paper, whiteboard }\end{array}$ & $\begin{array}{l}60 \\
\text { minutes }\end{array}$ \\
\hline 11 & $\begin{array}{l}\text { Case study of } \\
\text { demonstration plot } \\
\text { for integration of } \\
\text { teak, white ginger } \\
\text { and galangal }\end{array}$ & $\begin{array}{l}\text { Presentation of integrated } \\
\text { timber and non-timber } \\
\text { mixed garden concept } \\
\text { Integrated teak and white } \\
\text { ginger concept }\end{array}$ & $\begin{array}{l}\text { Participants understand different types of timber } \\
\text { and non-timber integrated agroforestry } \\
\text { management }\end{array}$ & $\begin{array}{l}\text { Presentation } \\
\text { Discussion } \\
\text { Brainstorming }\end{array}$ & $\begin{array}{l}\text { LCD projector, computer, } \\
\text { marker, metaplan paper, } \\
\text { plano paper, paper tape, } \\
\text { HVS paper, whiteboard }\end{array}$ & $\begin{array}{l}60 \\
\text { minutes }\end{array}$ \\
\hline 12 & $\begin{array}{l}\text { Observation of } \\
\text { white ginger and } \\
\text { galangal growth } \\
\text { under teak stocked } \\
\text { stands with branch } \\
\text { pruning and } \\
\text { thinning } \\
\text { treatments }\end{array}$ & $\begin{array}{l}\text { Observation of white ginger } \\
\text { and galangal growth under } \\
\text { teak stocked stands } \\
\text { Benefits of mixed farm } \\
\text { management at } \\
\text { demonstration site }\end{array}$ & $\begin{array}{l}\text { Participants understand timber and non-timber } \\
\text { integrated agroforestry management } \\
\text { Participants understand the differences in white } \\
\text { ginger and galangal growth for each pruning and } \\
\text { thinning treatment of teak crop }\end{array}$ & $\begin{array}{l}\text { Observatio } \\
\text { Discussion } \\
\text { Presentation }\end{array}$ & Writing tools, plano paper & $\begin{array}{l}180 \\
\text { minutes }\end{array}$ \\
\hline
\end{tabular}




\section{No. Topic}

13 Follow-up plan and activity evaluation

Post-test
Subjects

Follow-up plan and activity evaluation

Post-test for participants
Goals

Participants establish a post-training action plan

Participants' post-training conditions identified

\section{Methods}

Discussion

Rapid self-assessment
Instrument

Plano paper

Rapid self-assessment

form
Time

60

minutes 


\section{WORKING PAPERS WITH DOIs}

2005

1. Agroforestry in the drylands of eastern Africa: a call to action

2. Biodiversity conservation through agroforestry: managing tree species diversity within a network of community-based, nongovernmental, governmental and research organizations in western Kenya.

3. Invasion of prosopis juliflora and local livelihoods: Case study from the Lake Baringo area of Kenya

4. Leadership for change in farmers organizations: Training report: Ridar Hotel, Kampala, 29th March to 2nd April 2005.

5. Domestication des espèces agroforestières au Sahel : situation actuelle et perspectives

6. Relevé des données de biodiversité ligneuse: Manuel du projet biodiversité des parcs agroforestiers au Sahel

7. Improved land management in the Lake Victoria Basin: TransVic Project's draft report.

8. Livelihood capital, strategies and outcomes in the Taita hills of Kenya

9. Les espèces ligneuses et leurs usages: Les préférences des paysans dans le Cercle de Ségou, au Mali

10. La biodiversité des espèces ligneuses: Diversité arborée et unités de gestion du terroir dans le Cercle de Ségou, au Mali

\section{6}

11. Bird diversity and land use on the slopes of Mt. Kilimanjaro and the adjacent plains, Tanzania

12. Water, women and local social organization in the Western Kenya Highlands

13. Highlights of ongoing research of the World Agroforestry Centre in Indonesia

14. Prospects of adoption of tree-based systems in a rural landscape and its likely impacts on carbon stocks and farmers' welfare: The FALLOW Model Application in Muara Sungkai, Lampung, Sumatra, in a 'Clean Development Mechanism' context

15. Equipping integrated natural resource managers for healthy Agroforestry landscapes.

17. Agro-biodiversity and CGIAR tree and forest science: approaches and examples from Sumatra.

18. Improving land management in eastern and southern Africa: A review of policies.

19. Farm and household economic study of Kecamatan Nanggung, Kabupaten Bogor, Indonesia: A socio-economic base line study of Agroforestry innovations and livelihood enhancement.

20. Lessons from eastern Africa's unsustainable charcoal business.

21. Evolution of RELMA's approaches to land management: Lessons from two decades of research and development in eastern and southern Africa

22. Participatory watershed management: Lessons from RELMA's work with farmers in eastern Africa.

23. Strengthening farmers' organizations: The experience of RELMA and ULAMP.

24. Promoting rainwater harvesting in eastern and southern Africa.

25. The role of livestock in integrated land management.

26. Status of carbon sequestration projects in Africa: Potential benefits and challenges to scaling up. 
27. Social and Environmental Trade-Offs in Tree Species Selection: A Methodology for Identifying Niche Incompatibilities in Agroforestry [Appears as AHI Working Paper no. 9]

28. Managing tradeoffs in agroforestry: From conflict to collaboration in natural resource management. [Appears as AHI Working Paper no. 10]

29. Essai d'analyse de la prise en compte des systemes agroforestiers pa les legislations forestieres au Sahel: Cas du Burkina Faso, du Mali, du Niger et du Senegal.

30. Etat de la recherche agroforestière au Rwanda etude bibliographique, période 1987-2003

2007

31. Science and technological innovations for improving soil fertility and management in Africa: A report for NEPAD's Science and Technology Forum.

32. Compensation and rewards for environmental services.

33. Latin American regional workshop report compensation.

34. Asia regional workshop on compensation ecosystem services.

35. Report of African regional workshop on compensation ecosystem services.

36. Exploring the inter-linkages among and between compensation and rewards for ecosystem services CRES and human well-being

37. Criteria and indicators for environmental service compensation and reward mechanisms: realistic, voluntary, conditional and pro-poor

38. The conditions for effective mechanisms of compensation and rewards for environmental services.

39. Organization and governance for fostering Pro-Poor Compensation for Environmental Services.

40. How important are different types of compensation and reward mechanisms shaping poverty and ecosystem services across Africa, Asia \& Latin America over the Next two decades?

41. Risk mitigation in contract farming: The case of poultry, cotton, woodfuel and cereals in East Africa.

42. The RELMA savings and credit experiences: Sowing the seed of sustainability

43. Yatich J., Policy and institutional context for NRM in Kenya: Challenges and opportunities for Landcare.

44. Nina-Nina Adoung Nasional di So! Field test of rapid land tenure assessment (RATA) in the Batang Toru Watershed, North Sumatera.

45. Is Hutan Tanaman Rakyat a new paradigm in community based tree planting in Indonesia?

46. Socio-Economic aspects of brackish water aquaculture (Tambak) production in Nanggroe Aceh Darrusalam.

47. Farmer livelihoods in the humid forest and moist savannah zones of Cameroon.

48. Domestication, genre et vulnérabilité : Participation des femmes, des Jeunes et des catégories les plus pauvres à la domestication des arbres agroforestiers au Cameroun.

49. Land tenure and management in the districts around Mt Elgon: An assessment presented to the Mt Elgon ecosystem conservation programme.

50. The production and marketing of leaf meal from fodder shrubs in Tanga, Tanzania: A pro-poor enterprise for improving livestock productivity.

51. Buyers Perspective on Environmental Services (ES) and Commoditization as an approach to liberate ES markets in the Philippines. 
52. Towards Towards community-driven conservation in southwest China: Reconciling state and local perceptions.

53. Biofuels in China: An Analysis of the Opportunities and Challenges of Jatropha curcas in Southwest China.

54. Jatropha curcas biodiesel production in Kenya: Economics and potential value chain development for smallholder farmers

55. Livelihoods and Forest Resources in Aceh and Nias for a Sustainable Forest Resource Management and Economic Progress

56. Agroforestry on the interface of Orangutan Conservation and Sustainable Livelihoods in Batang Toru, North Sumatra.

2008

57. Assessing Hydrological Situation of Kapuas Hulu Basin, Kapuas Hulu Regency, West Kalimantan.

58. Assessing the Hydrological Situation of Talau Watershed, Belu Regency, East Nusa Tenggara.

59. Kajian Kondisi Hidrologis DAS Talau, Kabupaten Belu, Nusa Tenggara Timur.

60. Kajian Kondisi Hidrologis DAS Kapuas Hulu, Kabupaten Kapuas Hulu, Kalimantan Barat.

61. Lessons learned from community capacity building activities to support agroforest as sustainable economic alternatives in Batang Toru orang utan habitat conservation program (Martini, Endri et al.)

62. Mainstreaming Climate Change in the Philippines.

63. A Conjoint Analysis of Farmer Preferences for Community Forestry Contracts in the Sumber Jaya Watershed, Indonesia.

64. The highlands: a shared water tower in a changing climate and changing Asia

65. Eco-Certification: Can It Deliver Conservation and Development in the Tropics.

66. Designing ecological and biodiversity sampling strategies. Towards mainstreaming climate change in grassland management.

67. Towards mainstreaming climate change in grassland management policies and practices on the Tibetan Plateau

68. An Assessment of the Potential for Carbon Finance in Rangelands

69 ECA Trade-offs Among Ecosystem Services in the Lake Victoria Basin.

69. The last remnants of mega biodiversity in West Java and Banten: an in-depth exploration of RaTA (Rapid Land Tenure Assessment) in Mount Halimun-Salak National Park Indonesia

70. Le business plan d'une petite entreprise rurale de production et de commercialisation des plants des arbres locaux. Cas de quatre pépinières rurales au Cameroun.

71. Les unités de transformation des produits forestiers non ligneux alimentaires au Cameroun. Diagnostic technique et stratégie de développement Honoré Tabuna et Ingratia Kayitavu.

72. Les exportateurs camerounais de safou (Dacryodes edulis) sur le marché sous régional et international. Profil, fonctionnement et stratégies de développement.

73. Impact of the Southeast Asian Network for Agroforestry Education (SEANAFE) on agroforestry education capacity.

74. Setting landscape conservation targets and promoting them through compatible land use in the Philippines.

75. Review of methods for researching multistrata systems. 
76. Study on economical viability of Jatropha curcas L. plantations in Northern Tanzania assessing farmers' prospects via cost-benefit analysis

77. Cooperation in Agroforestry between Ministry of Forestry of Indonesia and International Center for Research in Agroforestry

78. "China's bioenergy future. an analysis through the Lens if Yunnan Province

79. Land tenure and agricultural productivity in Africa: A comparative analysis of the economics literature and recent policy strategies and reforms

80. Boundary organizations, objects and agents: linking knowledge with action in Agroforestry watersheds

81. Reducing emissions from deforestation and forest degradation (REDD) in Indonesia: options and challenges for fair and efficient payment distribution mechanisms

2009

82. Mainstreaming climate change into agricultural education: challenges and perspectives

83. Challenging conventional mindsets and disconnects in conservation: the emerging role of ecoagriculture in Kenya's landscape mosaics

84. Lesson learned RATA garut dan bengkunat: suatu upaya membedah kebijakan pelepasan kawasan hutan dan redistribusi tanah bekas kawasan hutan

85. The emergence of forest land redistribution in Indonesia

86. Commercial opportunities for fruit in Malawi

87. Status of fruit production processing and marketing in Malawi

88. Fraud in tree science

89. Trees on farm: analysis of global extent and geographical patterns of agroforestry

90. The springs of Nyando: water, social organization and livelihoods in Western Kenya

91. Building capacity toward region-wide curriculum and teaching materials development in agroforestry education in Southeast Asia

92. Overview of biomass energy technology in rural Yunnan (Chinese - English abstract)

93. A pro-growth pathway for reducing net GHG emissions in China

94. Analysis of local livelihoods from past to present in the central Kalimantan Ex-Mega Rice Project area

95. Constraints and options to enhancing production of high quality feeds in dairy production in Kenya, Uganda and Rwanda

2010

96. Agroforestry education in the Philippines: status report from the Southeast Asian Network for Agroforestry Education (SEANAFE)

97. Economic viability of Jatropha curcas L. plantations in Northern Tanzania- assessing farmers' prospects via cost-benefit analysis.

98. Hot spot of emission and confusion: land tenure insecurity, contested policies and competing claims in the central Kalimantan Ex-Mega Rice Project area

99. Agroforestry competences and human resources needs in the Philippines

100. CES/COS/CIS paradigms for compensation and rewards to enhance environmental Services 
101. Case study approach to region-wide curriculum and teaching materials development in agroforestry education in Southeast Asia

102. Stewardship agreement to reduce emissions from deforestation and degradation (REDD): Lubuk Beringin's Hutan Desa as the first village forest in Indonesia

103. Landscape dynamics over time and space from ecological perspective

104. Komoditisasi atau koinvestasi jasa lingkungan: skema imbal jasa lingkungan program peduli sungai di DAS Way Besai, Lampung, Indonesia

105. Improving smallholders' rubber quality in Lubuk Beringin, Bungo district, Jambi province, Indonesia: an initial analysis of the financial and social benefits

106. Rapid Carbon Stock Appraisal (RACSA) in Kalahan, Nueva Vizcaya, Philippines

107. Tree domestication by ICRAF and partners in the Peruvian Amazon: lessons learned and future prospects in the domain of the Amazon Initiative eco-regional program

108. Memorias del Taller Nacional: "Iniciativas para Reducir la Deforestación en la region Andino Amazónica”, 09 de Abril del 2010. Proyecto REALU Peru

109. Percepciones sobre la Equidad y Eficiencia en la cadena de valor de REDD en Perú -Reporte de Talleres en Ucayali, San Martín y Loreto, 2009. Proyecto REALU-Perú.

110. Reducción de emisiones de todos los Usos del Suelo. Reporte del Proyecto REALU Perú Fase 1

111. Programa Alternativas a la Tumba-y-Quema (ASB) en el Perú. Informe Resumen y Síntesis de la Fase II. 2da. versión revisada

112. Estudio de las cadenas de abastecimiento de germoplasma forestal en la amazonía Boliviana

113. Biodiesel in the Amazon

114. Estudio de mercado de semillas forestales en la amazonía Colombiana

115. Estudio de las cadenas de abastecimiento de germoplasma forestal en Ecuador http://dx.doi.org10.5716/WP10340.PDF

116. How can systems thinking, social capital and social network analysis help programs achieve impact at scale?

117. Energy policies, forests and local communities in the Ucayali Region, Peruvian Amazon

118. NTFPs as a Source of Livelihood Diversification for Local Communities in the Batang Toru Orangutan Conservation Program

119. Studi Biodiversitas: Apakah agroforestry mampu mengkonservasi keanekaragaman hayati di DAS Konto?

120. Estimasi Karbon Tersimpan di Lahan-lahan Pertanian di DAS Konto, Jawa Timur

121. Implementasi Kaji Cepat Hidrologi (RHA) di Hulu DAS Brantas, Jawa Timur. http://dx.doi.org/10.5716/WP10338.PDF

122. Kaji Cepat Hidrologi di Daerah Aliran Sungai Krueng Peusangan, NAD,Sumatra http://dx.doi.org/10.5716/WP10337.PDF

123. A Study of Rapid Hydrological Appraisal in the Krueng Peusangan Watershed, NAD, Sumatra. http://dx.doi.org/10.5716/WP10339.PDF

2011

124. An Assessment of farm timber value chains in Mt Kenya area, Kenya

125. A Comparative financial analysis of current land use systems and implications for the adoption of improved agroforestry in the East Usambaras, Tanzania

126. Agricultural monitoring and evaluation systems 
127. Challenges and opportunities for collaborative landscape governance in the East Usambara Mountains, Tanzania

128. Transforming Knowledge to Enhance Integrated Natural Resource Management Research, Development and Advocacy in the Highlands of Eastern Africa http://dx.doi.org/10.5716/WP11084.PDF

129. Carbon-forestry projects in the Philippines: potential and challenges The Mt Kitanglad Range forest-carbon development http://dx.doi.org10.5716/WP11054.PDF

130. Carbon forestry projects in the Philippines: potential and challenges. The Arakan Forest Corridor forest-carbon project. http://dx.doi.org10.5716/WP11055.PDF

131. Carbon-forestry projects in the Philippines: potential and challenges. The Laguna Lake Development Authority's forest-carbon development project. http://dx.doi.org/10.5716/WP11056.PDF

132. Carbon-forestry projects in the Philippines: potential and challenges. The Quirino forest-carbon development project in Sierra Madre Biodiversity Corridor http://dx.doi.org10.5716/WP11057.PDF

133. Carbon-forestry projects in the Philippines: potential and challenges. The Ikalahan Ancestral Domain forest-carbon development http://dx.doi.org10.5716/WP11058.PDF

134. The Importance of Local Traditional Institutions in the Management of Natural Resources in the Highlands of Eastern Africa. http://dx.doi.org/10.5716/WP11085.PDF

135. Socio-economic assessment of irrigation pilot projects in Rwanda. http://dx.doi.org/10.5716/WP11086.PDF

136. Performance of three rambutan varieties (Nephelium lappaceum L.) on various nursery media. http://dx.doi.org/10.5716/WP11232.PDF

137. Climate change adaptation and social protection in agroforestry systems: enhancing adaptive capacity and minimizing risk of drought in Zambia and Honduras http://dx.doi.org/10.5716/WP11269.PDF

138. Does value chain development contribute to rural poverty reduction? Evidence of asset building by smallholder coffee producers in Nicaragua http://dx.doi.org/10.5716/WP11271.PDF

139. Potential for biofuel feedstock in Kenya. http://dx.doi.org/10.5716/WP11272.PDF

140. Impact of fertilizer trees on maize production and food security in six districts of Malawi. http://dx.doi.org/10.5716/WP11281.PDF

2012

141. Fortalecimiento de capacidades para la gestión del Santuario Nacional Pampa Hermosa: Construyendo las bases para un manejo adaptativo para el desarrollo local. Memorias del Proyecto. http://dx.doi.org/10.5716/WP12005.PDF

142. Understanding rural institutional strengthening: A cross-level policy and institutional framework for sustainable development in Kenya http://dx.doi.org/10.5716/WP12012.PDF

143. Climate change vulnerability of agroforestry http://dx.doi.org/10.5716/WP16722.PDF

144. Rapid assesment of the inner Niger delta of Mali http://dx.doi.org/10.5716/WP12021.PDF

145. Designing an incentive program to reduce on-farm deforestationin the East Usambara Mountains, Tanzania http://dx.doi.org/10.5716/WP12048.PDF

146. Extent of adoption of conservation agriculture and agroforestry in Africa: the case of Tanzania, Kenya, Ghana, and Zambia http://dx.doi.org/10.5716/WP12049.PDF 
147. Policy incentives for scaling up conservation agriculture with trees in Africa: the case of Tanzania, Kenya, Ghana and Zambia http://dx.doi.org/10.5716/WP12050.PDF

148. Commoditized or co-invested environmental services? Rewards for environmental services scheme: River Care program Way Besai watershed, Lampung, Indonesia. http://dx.doi.org/10.5716/WP12051.PDF

149. Assessment of the headwaters of the Blue Nile in Ethiopia. http://dx.doi.org/10.5716/WP12160.PDF

150. Assessment of the uThukela Watershed, Kwazaulu. http://dx.doi.org/10.5716/WP12161.PDF

151. Assessment of the Oum Zessar Watershed of Tunisia. http://dx.doi.org/10.5716/WP12162.PDF

152. Assessment of the Ruwenzori Mountains in Uganda. http://dx.doi.org/10.5716/WP12163.PDF

153. History of agroforestry research and development in Viet Nam. Analysis of research opportunities and gaps. http://dx.doi.org/10.5716/WP12052.PDF

154. REDD+ in Indonesia: a Historical Perspective. http://dx.doi.org/10.5716/WP12053.PDF

155. Agroforestry and Forestry in Sulawesi series: Livelihood strategies and land use system dynamics in South Sulawesi http://dx.doi.org/10.5716/WP12054.PDF

156. Agroforestry and Forestry in Sulawesi series: Livelihood strategies and land use system dynamics in Southeast Sulawesi. http://dx.doi.org/10.5716/WP12055.PDF

157. Agroforestry and Forestry in Sulawesi series: Profitability and land-use systems in South and Southeast Sulawesi. http://dx.doi.org/10.5716/WP12056.PDF

158. Agroforestry and Forestry in Sulawesi series: Gender, livelihoods and land in South and Southeast Sulawesi http://dx.doi.org/10.5716/WP12057.PDF

159. Agroforestry and Forestry in Sulawesi series: Agroforestry extension needs at the community level in AgFor project sites in South and Southeast Sulawesi, Indonesia. http://dx.doi.org/10.5716/WP12058.PDF

160. Agroforestry and Forestry in Sulawesi series: Rapid market appraisal of agricultural, plantation and forestry commodities in South and Southeast Sulawesi. http://dx.doi.org/10.5716/WP12059.PDF

2013

161. Diagnosis of farming systems in the Agroforestry for Livelihoods of Smallholder farmers in Northwestern Viet Nam project http://dx.doi.org/10.5716/WP13033.PDF

162. Ecosystem vulnerability to climate change: a literature review. http://dx.doi.org/10.5716/WP13034.PDF

163. Local capacity for implementing payments for environmental services schemes: lessons from the RUPES project in northeastern Viet Nam http://dx.doi.org/10.5716/WP13046.PDF

164. Seri Agroforestri dan Kehutanan di Sulawesi: Agroforestry dan Kehutanan di Sulawesi: Strategi mata pencaharian dan dinamika sistem penggunaan lahan di Sulawesi Selatan http://dx.doi.org/10.5716/WP13040.PDF

165. Seri Agroforestri dan Kehutanan di Sulawesi: Mata pencaharian dan dinamika sistem penggunaan lahan di Sulawesi Tenggara http://dx.doi.org/10.5716/WP13041.PDF

166. Seri Agroforestri dan Kehutanan di Sulawesi: Profitabilitas sistem penggunaan lahan di Sulawesi Selatan dan Sulawesi Tenggara http://dx.doi.org/10.5716/WP13042.PDF

167. Seri Agroforestri dan Kehutanan di Sulawesi: Gender, mata pencarian dan lahan di Sulawesi Selatan dan Sulawesi Tenggara http://dx.doi.org/10.5716/WP13043.PDF 
168. Seri Agroforestri dan Kehutanan di Sulawesi: Kebutuhan penyuluhan agroforestri pada tingkat masyarakat di lokasi proyek AgFor di Sulawesi Selatan dan Tenggara, Indonesia. http://dx.doi.org/10.5716/WP13044.PDF

169. Seri Agroforestri dan Kehutanan di Sulawesi: Laporan hasil penilaian cepat untuk komoditas pertanian, perkebunan dan kehutanan di Sulawesi Selatan dan Tenggara http://dx.doi.org/10.5716/WP13045.PDF

170. Agroforestry, food and nutritional security http://dx.doi.org/10.5716/WP13054.PDF

171. Stakeholder Preferences over Rewards for Ecosystem Services: Implications for a REDD+ Benefit Distribution System in Viet Nam http://dx.doi.org/10.5716/WP13057.PDF

172. Payments for ecosystem services schemes: project-level insights on benefits for ecosystems and the rural poor http://dx.doi.org/10.5716/WP13001.PDF

173. Good practices for smallholder teak plantations: keys to success http://dx.doi.org/10.5716/WP13246.PDF

174. Market analysis of selected agroforestry products in the Vision for Change Project intervention Zone, Côte d'Ivoire http://dx.doi.org/10.5716/WP13249.PDF

175. Rattan futures in Katingan: why do smallholders abandon or keep their gardens in Indonesia's 'rattan district'? http://dx.doi.org/10.5716/WP13251.PDF

176. Management along a gradient: the case of Southeast Sulawesi's cacao production landscapes http://dx.doi.org/10.5716/WP13265.PDF

2014

177. Are trees buffering ecosystems and livelihoods in agricultural landscapes of the Lower Mekong Basin? Consequences for climate-change adaptation. http://dx.doi.org/10.5716/WP14047.PDF

178. Agroforestry, livestock, fodder production and climate change adaptation and mitigation in East Africa: issues and options. http://dx.doi.org/10.5716/WP14050.PDF

179. Trees on farms: an update and reanalysis of agroforestry's global extent and socio-ecological characteristics. http://dx.doi.org/10.5716/WP14064.PDF

180. Beyond reforestation: an assessment of Vietnam's REDD+ readiness. http://dx.doi.org/10.5716/WP14097.PDF

181. Farmer-to-farmer extension in Kenya: the perspectives of organizations using the approach. http://dx.doi.org/10.5716/WP14380.PDF

182. Farmer-to-farmer extension in Cameroon: a survey of extension organizations. http://dx.doi.org/10.5716/WP14383.PDF

183. Farmer-to-farmer extension approach in Malawi: a survey of organizations: a survey of organizations http://dx.doi.org/10.5716/WP14391.PDF

184. Seri Agroforestri dan Kehutanan di Sulawesi: Kuantifikasi jasa lingkungan air dan karbon pola agroforestri pada hutan rakyat di wilayah sungai Jeneberang

185. Options for Climate-Smart Agriculture at Kaptumo Site in Kenyahttp://dx.doi.org/10.5716/WP14394.PDF

2015

186. Agroforestry for Landscape Restoration and Livelihood Development in Central Asia http://dx.doi.org/10.5716/WP14143.PDF 
187. "Projected Climate Change and Impact on Bioclimatic Conditions in the Central and SouthCentral Asia Region" http://dx.doi.org/10.5716/WP14144.PDF

188. Land Cover Changes, Forest Loss and Degradation in Kutai Barat, Indonesia. http://dx.doi.org/10.5716/WP14145.PDF

189. The Farmer-to-Farmer Extension Approach in Malawi: A Survey of Lead Farmers. http://dx.doi.org/10.5716/WP14152.PDF

190. Evaluating indicators of land degradation and targeting agroforestry interventions in smallholder farming systems in Ethiopia. http://dx.doi.org/10.5716/WP14252.PDF

191. Land health surveillance for identifying land constraints and targeting land management options in smallholder farming systems in Western Cameroon

192. Land health surveillance in four agroecologies in Malawi

193. Cocoa Land Health Surveillance: an evidence-based approach to sustainable management of cocoa landscapes in the Nawa region, South-West Côte d'Ivoire http://dx.doi.org/10.5716/WP14255.PDF

194. Situational analysis report: Xishuangbanna autonomous Dai Prefecture, Yunnan Province, China. http://dx.doi.org/10.5716/WP14255.PDF

195. Farmer-to-farmer extension: a survey of lead farmers in Cameroon. http://dx.doi.org/10.5716/WP15009.PDF

196. From transition fuel to viable energy source Improving sustainability in the sub-Saharan charcoal sector http://dx.doi.org/10.5716/WP15011.PDF

197. Mobilizing Hybrid Knowledge for More Effective Water Governance in the Asian Highlands http://dx.doi.org/10.5716/WP15012.PDF

198. Water Governance in the Asian Highlands http://dx.doi.org/10.5716/WP15013.PDF

199. Assessing the Effectiveness of the Volunteer Farmer Trainer Approach in Dissemination of Livestock Feed Technologies in Kenya vis-à-vis other Information Sources http://dx.doi.org/10.5716/WP15022.PDF

200. The rooted pedon in a dynamic multifunctional landscape: Soil science at the World Agroforestry Centre http://dx.doi.org/10.5716/WP15023.PDF

201. Characterising agro-ecological zones with local knowledge. Case study: Huong Khe district, $\mathrm{Ha}$ Tinh, Viet Nam http://dx.doi.org/10.5716/WP15050.PDF

202. Looking back to look ahead: Insight into the effectiveness and efficiency of selected advisory approaches in the dissemination of agricultural technologies indicative of Conservation Agriculture with Trees in Machakos County, Kenya. http://dx.doi.org/10.5716/WP15065.PDF

203. Pro-poor Biocarbon Projects in Eastern Africa Economic and Institutional Lessons. http://dx.doi.org/10.5716/WP15022.PDF

204. Projected climate change impacts on climatic suitability and geographical distribution of banana and coffee plantations in Nepal. http://dx.doi.org/10.5716/WP15294.PDF

205. Agroforestry and Forestry in Sulawesi series: Smallholders' coffee production and marketing in Indonesia. A case study of two villages in South Sulawesi Province. http://dx.doi.org/10.5716/WP15690.PDF

206. Mobile phone ownership and use of short message service by farmer trainers: a case study of Olkalou and Kaptumo in Kenya http://dx.doi.org/10.5716/WP15691.PDF

207. Associating multivariate climatic descriptors with cereal yields: a case study of Southern Burkina Faso http://dx.doi.org/10.5716/WP15273.PDF

208. Preferences and adoption of livestock feed practices among farmers in dairy management groups in Kenya http://dx.doi.org/10.5716/WP15675.PDF 
209. Scaling up climate-smart agriculture: lessons learned from South Asia and pathways for success http://dx.doi.org/10.5716/WP15720.PDF

210. Agroforestry and Forestry in Sulawesi series: Local perceptions of forest ecosystem services and collaborative formulation of reward mechanisms in South and Southeast Sulawesi http://dx.doi.org/10.5716/WP15721.PDF

211. Potential and challenges in implementing the co-investment of ecosystem services scheme in Buol District, Indonesia. http://dx.doi.org/10.5716/WP15722.PDF

212. Tree diversity and its utilization by the local community in Buol District, Indonesia http://dx.doi.org/10.5716/WP15723.PDF

213 Vulnerability of smallholder farmers and their preferences on farming practices in Buol District, Indonesia http://dx.doi.org/10.5716/WP15724.PDF

214. Dynamics of Land Use/Cover Change and Carbon Emission in Buol District, Indonesia http://dx.doi.org/10.5716/WP15725.PDF

215. Gender perspective in smallholder farming practices in Lantapan, Phillippines. http://dx.doi.org/10.5716/WP15726.PDF

216. Vulnerability of smallholder farmers in Lantapan, Bukidnon. http://dx.doi.org/10.5716/WP15727.PDF

217. Vulnerability and adaptive capacity of smallholder farmers in Ho Ho Sub-watershed, Ha Tinh Province, Vietnam http://dx.doi.org/10.5716/WP15728.PDF

218. Local Knowledge on the role of trees to enhance livelihoods and ecosystem services in northern central Vietnam http://dx.doi.org/10.5716/WP15729.PDF

219. Land-use/cover change in Ho Ho Sub-watershed, Ha Tinh Province, Vietnam. http://dx.doi.org/10.5716/WP15730.PDF

2016

220. Agroforestry and Forestry in Sulawesi series: Evaluation of the Agroforestry Farmer Field Schools on agroforestry management in South and Southeast Sulawesi, Indonesia. http://dx.doi.org/10.5716/WP16002.PDF

221. Farmer-to-farmer extension of livestock feed technologies in Rwanda: A survey of volunteer farmer trainers and organizations. http://dx.doi.org/10.5716/WP16005.PDF

222. Projected Climate Change Impact on Hydrology, Bioclimatic Conditions, and Terrestrial Ecosystems in the Asian Highlands http://dx.doi.org/10.5716/WP16006.PDF

223. Adoption of Agroforestry and its impact on household food security among farmers in Malawi http://dx.doi.org/10.5716/WP16013.PDF

224. Agroforestry and Forestry in Sulawesi series: Information channels for disseminating innovative agroforestry practices to villages in Southern Sulawesi, Indonesia http://dx.doi.org/10.5716/WP16034.PDF

225. Agroforestry and Forestry in Sulawesi series: Unravelling rural migration networks.Landtenure arrangements among Bugis migrant communities in Southeast Sulawesi. http://dx.doi.org/10.5716/WP16035.PDF

226. Agroforestry and Forestry in Sulawesi series: Women's participation in agroforestry: more benefit or burden? A gendered analysis of Gorontalo Province. http://dx.doi.org/10.5716/WP16036.PDF

227. Kajian Kelayakan dan Pengembangan Desain Teknis Rehabilitasi Pesisir di Sulawesi Tengah. http://dx.doi.org/10.5716/WP16037.PDF

228. Selection of son tra clones in North West Vietnam. http://dx.doi.org/10.5716/WP16038.PDF 
229. Growth and fruit yield of seedlings, cuttings and grafts from selected son tra trees in Northwest Vietnam http://dx.doi.org/10.5716/WP16046.PDF

230. Gender-Focused Analysis of Poverty and Vulnerability in Yunnan, China http://dx.doi.org/10.5716/WP16071.PDF

231. Seri Agroforestri dan Kehutanan di Sulawesi: Kebutuhan Penyuluhan Agroforestri untuk Rehabilitasi Lahan di Sumba Timur, Nusa Tenggara Timur, Indonesia. http://dx.doi.org/10.5716/WP16077.PDF

232. Agroforestry and Forestry in Sulawesi series: Agroforestry extension needs for land rehabilitation in East Sumba, East Nusa Tenggara, Indonesia. http://dx.doi.org/10.5716/WP16078.PDF

233. Central hypotheses for the third agroforestry paradigm within a common definition. http://dx.doi.org/10.5716/WP16079.PDF

234. Assessing smallholder farmers' interest in shade coffee trees: The Farming Systems of Smallholder Coffee Producers in the Gisenyi Area, Rwanda: a participatory diagnostic study. http://dx.doi.org/10.5716/WP16104.PDF

235. Review of agricultural market information systems in /sub-Saharan Africa. http://dx.doi.org/10.5716/WP16110.PDF

236. Vision and road map for establishment of a protected area in Lag Badana, Lower Jubba, Somalia. http://dx.doi.org/10.5716/WP16127.PDF

237. Replicable tools and frameworks for Bio-Carbon Development in West Africa. http://dx.doi.org/10.5716/WP16138.PDF

238. Existing Conditions, Challenges and Needs in the Implementation of Forestry and Agroforestry Extension in Indonesia. http://dx.doi.org/10.5716/WP16141.PDF

239. Situasi Terkini, Tantangan dan Kebutuhan Pelaksanaan Penyuluhan Kehutanan dan Agroforestri di Indonesia. http://dx.doi.org/10.5716/WP16142.PDF

240. The national agroforestry policy of India: experiential learning in development and delivery phases. http://dx.doi.org/10.5716/WP16143.PDF

241. Agroforestry and Forestry in Sulawesi series: Livelihood strategies and land-use system dynamics in Gorontalo. http://dx.doi.org/10.5716/WP16157.PDF

242. Seri Agroforestri dan Kehutanan di Sulawesi: Strategi mata pencaharian dan dinamika sistem penggunaan lahan di Gorontalo. http://dx.doi.org/10.5716/WP16158.PDF

243. Ruang, Gender dan Kualitas Hidup Manusia: Sebuah studi Gender pada komunitas perantau dan pengelola kebun di Jawa Barat. http://dx.doi.org/10.5716/WP16159.PDF

244. Gendered Knowledge and perception in managing grassland areas in East Sumba, Indonesia. http://dx.doi.org/10.5716/WP16160.PDF

245. Pengetahuan dan persepsi masyarakat pengelola padang aavana, Sebuah Kajian Gender di Sumba Timur. http://dx.doi.org/10.5716/WP16161.PDF

246. Dinamika Pengambilan Keputusan pada komunitas perantau dan pengelola kebun di Jawa Barat. http://dx.doi.org/10.5716/WP16162.PDF

247. Gaharu (eaglewood) domestication: Biotechnology, markets and agroforestry options. http://dx.doi.org/10.5716/WP16163.PDF

248. Marine habitats of the Lamu-Kiunga coast: an assessment of biodiversity value, threats and opportunities. http://dx.doi.org/10.5716/WP16167.PDF

249. Assessment of the biodiversity in terrestrial landscapes of the Witu protected area and surroundings, Lamu County Kenya. http://dx.doi.org/10.5716/WP16172.PDF

250. An ecosystem services perspective on benefits that people derive from biodiversity of Coastal forests in Lamu County, Kenya http://dx.doi.org/10.5716/WP16173.PDF 
251. Assessment of the biodiversity in terrestrial and marine landscapes of the proposed Laga Badana National Park and surrounding areas, Jubaland, Somalia.

http://dx.doi.org/10.5716/WP16174.PDF

2017

252. Preferensi Petani terhadap Topik Penyuluhan dan Penyebaran Informasi Agroforestri di Indonesia. http://dx.doi.org/10.5716/WP16181.PDF

253. Seri Agroforestri dan Kehutanan di Sulawesi: Keanekaragaman hayati jenis pohon pada hutan rakyat agroforestri di DAS Balangtieng, Sulawesi Selatan. http://dx.doi.org/10.5716/WP16182.PDF

254. Potensi dan Tantangan dalam Pengembangan Skema Ko-Investasi Jasa Lingkungan di Kabupaten Buol, Indonesia. http://dx.doi.org/10.5716/WP17008.PDF

255. Keragaman Jenis Pohon dan Pemanfaatannya oleh Masyarakat di Kabupaten Buol, Indonesia. http://dx.doi.org/10.5716/WP17009.PDF

256. Kerentanan dan preferensi sistem pertanian petani di Kabupaten Buol, Indonesia. http://dx.doi.org/10.5716/WP17010.PDF

257. Dinamika Perubahan Penggunaan/Tutupan Lahan Serta Cadangan Karbon di Kabupaten Buol, Indonesia. http://dx.doi.org/10.5716/WP17011.PDF

258. The Effectiveness of the Volunteer Farmer Trainer Approach vis-à-vis Other Information Sources in Dissemination of Livestock Feed Technologies in Uganda. http://dx.doi.org/10.5716/WP17104.PDF

259. Agroforestry and Forestry in Sulawesi series: Impact of agricultural-extension booklets on community livelihoods in South and Southeast Sulawesi. http://dx.doi.org/10.5716/WP17125.PDF

260. Petani Menjadi Penyuluh, Mungkinkah? Sebuah Pendekatan Penyuluhan dari Petani ke Petani di Kabupaten Sumba Timur. http://dx.doi.org/10.5716/WP17145.PDF

261. Dampak Perubahan Tutupan Lahan terhadap Kondisi Hidrologi di Das Buol, Kabupaten Buol, Sulawesi Tengah: Simulasi dengan Model Genriver. http://dx.doi.org/10.5716/WP17146.PDF

262. Analisis Tapak Mata Air Umbulan, Pasuruan, Jawa Timur. Kajian elemen biofisik dan persepsi masyarakat. http://dx.doi.org/10.5716/WP17147.PDF

263. Planned comparisons demystified. http://dx.doi.org/10.5716/WP17354.PDF

264. Soil health decision support for NERC digital soil platforms: A survey report. http://dx.doi.org/10.5716/WP17355.PDF

265. Seri Pembangunan Ekonomi Pedesaan Indonesia: Menanam di bukit gundul: Pengetahuan masyarakat lokal dalam upaya restorasi lahan di Sumba

Timur. http://dx.doi.org/10.5716/WP17356.PDF

266. Tree diversity and carbon stock in three districts of Kutai Timur, Pasir and Berau, East Kalimantan http://dx.doi.org/10.5716/WP17357.PDF

267. Tree Diversity and Carbon Stock in Various Land Use Systems of Banyuasin and Musi Banyuasin Districts, South Sumatera http://dx.doi.org/10.5716/WP17358.PDF

268. Tree diversity and carbon stock in various land cover systems of Jayapura, Jayawijaya and Merauke Districts, Papua Province http://dx.doi.org/10.5716/WP17359.PDF

269. Modelling tree production based on farmers' knowledge: case for kapok (Ceiba pentandra) and candlenut (Aleurites mollucana) under various agroforestry scenarios.

http://dx.doi.org/10.5716/WP17361.PDF 
270. The Impact of Land Cover and Climate Change on Present and Future Watershed Condition. Study case: Tugasan, Alanib and Kulasihan Sub-watershed of Manupali Watershed, Lantapan, Bukidnon, Philippines. http://dx.doi.org/10.5716/WP17362.PDF

271. Tree Diversity and Above-ground Carbon Stock estimation in Various Land use Systems in Banjarnegara, Banyumas and Purbalingga, Central Java. http://dx.doi.org/10.5716/WP17363.PDF

272. Agroforestry and Forestry in Sulawesi series: Landscape Management Strategies in Sulawesi: Review of Intervention Options. http://dx.doi.org/10.5716/WP17364.PDF

273. Household Food-Security and Nutritional Status of Women and Children in Buol Regency, Central Sulawesi, Indonesia. http://dx.doi.org/10.5716/WP17365.PDF

274. Palm oil expansion in tropical forest margins or sustainability of production? Focal issues of regulations and private standards. http://dx.doi.org/10.5716/WP17366.PDF

2018

275. Decision analysis methods guide: agricultural policy for nutrition http://dx.doi.org/10.5716/WP18001.PDF

276. Supporting human nutrition in Africa through the integration of new and orphan crops into food systems: Placing the work of the African Orphan Crops Consortium in context. http://dx.doi.org/10.5716/WP18003.PDF

277. Seri Pembangunan Ekonomi Pedesaan Indonesia. Pilihan Manajemen Budidaya Kacang Tanah sebagai Upaya untuk Memperbaiki Penghidupan Masyarakat Haharu. http://dx.doi.org/10.5716/WP18004.PDF

278. Estudio de línea de base CCAFS a nivel de hogar en Nicaragua y Costa Rica. Fase de diagnóstico del estudio: "Contribución de la diversidad arbórea a los medios de vida para la adaptación y la mitigación al cambio climático. http://dx.doi.org/10.5716/WP18005.PDF

279. Understanding tree cover transition, drivers and stakeholder perspectives for effective landscape governance. A case study in Na Nhan commune, Dien Bien province, Vietnam. http://dx.doi.org/10.5716/WP18006.PDF

280. El Sistema "Quesungual": Agroforestería y manejo de suelos para la producción de maíz y frijol en laderas. http://dx.doi.org/10.5716/WP18007.PDF

281. Probabilistic Decision Modelling to Determine Impacts on Natural Resource Management and Livelihood Resilience in Marsabit County, Kenya. http://dx.doi.org/10.5716/WP18008.PDF

282. Shifting discourse, shifting power: how is climate change mitigation and justice negotiated in Indonesia? http://dx.doi.org/10.5716/WP18009.PDF

283. Result of Land Use Planning and Land Administration (LULA) Implementation in South Sumatra, East Kalimantan, Central Java and Papua. http://dx.doi.org/10.5716/WP18010.PDF

284. Farmers' preferences for training topics and dissemination of agroforestry information in Indonesia. http://dx.doi.org/10.5716/WP18015.PDF 

The World Agroforestry Centre is an autonomous, non-profit research organization whose vision is a rural transformation in the developing world as smallholder households increase their use of trees in agricultural landscapes to improve food security, nutrition, income, health, shelter, social cohesion, energy resources and environmental sustainability. The Centre generates science-based knowledge about the diverse roles that trees play in agricultural landscapes, and uses its research to advance policies and practices, and their implementation that benefit the poor and the environment. It aims to ensure that all this is achieved by enhancing the quality of its science work, increasing operational efficiency, building and maintaining strong partnerships, accelerating the use and impact of its research, and promoting greater cohesion, interdependence and alignment within the organization.

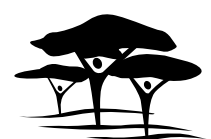

United Nations Avenue, Gigiri • PO Box 30677 • Nairobi, $00100 \cdot$ Kenya Telephone: +254 207224000 or via USA +1 6508336645 Fax: +254207224001 or via USA +1 6508336646

Email: worldagroforestry@cgiar.org•www.worldagroforestry.org

Southeast Asia Regional Program • Sindang Barang • Bogor 16680

PO Box $161 \cdot$ Bogor $16001 \cdot$ Indonesia

Telephone: +62 2518625415 • Fax: +62 2518625416

- Email: icraf-indonesia@cgiar.org

www.worldagroforestry.org/region/southeast-asia

blog.worldagroforestry.org 